\title{
Chlorine-induced high temperature corrosion of HVAF-sprayed Ni-based alumina and chromia forming coatings
}

Esmaeil Sadeghimeresht ${ }^{\mathrm{a} 1}$, Liam Reddy ${ }^{\mathrm{b}}$, Tanvir Hussain ${ }^{\mathrm{b}}$, Nicolaie Markocsan $^{\mathrm{a}}$, Shrikant Joshi ${ }^{\mathrm{a}}$

${ }^{a}$ Department of Engineering Science, University West, 46153 Trollhättan, Sweden

${ }^{b}$ Faculty of Engineering, The University of Nottingham, Nottingham NG7 2RD, UK

\begin{abstract}
Chlorine-induced corrosion of HVAF-sprayed Ni21Cr and Ni5Al coatings was investigated in 5 vol.\% $\mathrm{O}_{2}+500 \mathrm{vppm} \mathrm{HCl}+\mathrm{N}_{2}$ with and without $\mathrm{KCl}$ at $600^{\circ} \mathrm{C}$ up to $168 \mathrm{~h}$. Both coatings were protective in the absence of $\mathrm{KCl}$. With $\mathrm{KCl}$, Ni21Cr degraded through a two-stage mechanism: 1) formation of $\mathrm{K}_{2} \mathrm{CrO}_{4}$ followed by diffusion of $\mathrm{Cl}^{-}$through the oxide grain boundaries to yield chlorine and a nonprotective oxide, and 2) inward diffusion of chlorine though defects in the non-protective oxide, leading to breakaway oxidation. $\mathrm{Cl}^{-} / \mathrm{Cl}_{2}$ could not diffuse through the protective alumina scale formed on $\mathrm{Ni} 5 \mathrm{Al}$, hence the corrosion resistance increased.
\end{abstract}

\section{Keywords:}

A. Thermal Spray Coating; NiCr; NiAl;

B. High-Velocity Air Fuel (HVAF); Biomass-/Waste-Fired Boiler;

C. Fireside Corrosion

${ }^{1}$ Corresponding author: E-mail address: esmaeil.sadeghimeresht@hv.se (E. Sadeghimeresht) 


\section{Introduction}

The power generation industry has been rapidly shifting towards utilization of more ecologically compliant biomass and waste fuels like straw and municipal solid wastes (MSW) to reduce usage of traditional fuels as well as lower $\mathrm{CO}_{2}$ emissions [1]. However, combustion of such fuels inevitably produces significant amounts of harsh corrosive species such as chlorine $\left(\mathrm{Cl}_{2}\right)$, hydrogen chloride $(\mathrm{HCl})$ and alkali chlorides (e.g., $\mathrm{KCl}$, or $\mathrm{NaCl}$ ) which accelerate corrosion of boiler components, in particular water-wall and superheater tubes [2]. It was proposed by Lee and McNallan [3] and further investigated by Grabke and Zahs [4] that these corrosive compounds react with the alloying elements present in the boiler components, and trigger accelerated corrosion through the "chlorine-active corrosion" mechanism. $\mathrm{Cl}_{2}$ sourced from alkali chlorides (Eq. 1) diffuses through the defects in the oxide scale (e.g., cracks and pores) towards the metal/scale interface. Formation of metal chlorides can be accelerated when less oxygen (or lower oxygen partial pressure - $p \mathrm{O}_{2}$ ) is present. At temperatures above $400{ }^{\circ} \mathrm{C}$, evaporation of the metal chlorides and their subsequent outward diffusion towards the gas/scale interface occur. The gaseous metal chlorides convert to oxides where more oxygen $\left(\approx\right.$ higher $\left.p \mathrm{O}_{2}\right)$ is available. The new oxides form within the cracks and pores of the existing oxide scale, leading to subsequent cracking and spallation of the oxide [4]. However, the initiation of corrosion, i.e. breakdown of the Cr-rich protective oxide initially present on chromia forming alloys, cannot be explained by this mechanism. The $\mathrm{Cl}_{2}$ diffusion through the cracks and pores of the scale is also not well explained. Moreover, $\mathrm{K}_{2} \mathrm{CrO}_{4}$ formed through the proposed mechanism (Eq. 1) is also not thermodynamically favoured, and hence non-spontaneous [5].

$\mathrm{Cr}_{2} \mathrm{O}_{3}(s)+4 \mathrm{KCl}(s)+\frac{5}{2} \mathrm{O}_{2}(g) \rightarrow 2 \mathrm{~K}_{2} \mathrm{CrO}_{4}(s)+2 \mathrm{Cl}_{2}(\mathrm{~g})$

$\Delta G_{f}^{0}\left(\mathrm{~K}_{2} \mathrm{CrO}_{4}\right) \approx 73.8 \mathrm{~kJ} / \mathrm{mol}$ at $600^{\circ} \mathrm{C}$

In another proposed theory, known as "electrochemical mechanism" [6], the alkali chlorides react with $\mathrm{Cr}$ in the protective oxide scale to form $\mathrm{K}_{2} \mathrm{CrO}_{4}$ at early stages, leading to a $\mathrm{Cr}$-depleted oxides and thereby breakaway oxidation. After this initial step, $\mathrm{Cl}^{-}$diffuses through the oxide grain boundaries towards the metal/oxide interface via electrochemical reactions [7]. It should be noted that in both the above proposed mechanisms, the reaction of $\mathrm{KCl}$ with $\mathrm{Al}_{2} \mathrm{O}_{3}$ which produces potassium aluminate $\left(\mathrm{KAlO}_{2}\right)$ is much less thermodynamically favoured than the formation of $\mathrm{K}_{2} \mathrm{CrO}_{4}$ (Eq. 2) [8].

$$
\begin{aligned}
& \mathrm{Al}_{2} \mathrm{O}_{3}(s)+2 \mathrm{KCl}(s)+\frac{1}{2} \mathrm{O}_{2}(g) \rightarrow 2 \mathrm{KAlO}_{2}(s)+2 \mathrm{Cl}_{2}(g) \\
& \Delta G_{f}^{0}\left(\mathrm{KAlO}_{2}\right) \approx 112.5 \mathrm{~kJ} / \mathrm{mol} \text { at } 600{ }^{\circ} \mathrm{C}
\end{aligned}
$$

To avoid high corrosion rates caused by $\mathrm{Cl}^{-}$or $\mathrm{Cl}_{2}$ and increase the lifetime of boiler components, two practical and widely accepted solutions involve utilizing highly alloyed materials [9] or by reducing the 
operating temperatures [10]. Such advanced highly alloyed materials are complex, time consuming to develop and extremely expensive, while reducing the working temperature significantly decreases the boiler's efficiency; hence, the above solutions are not always attractive both economically and technically. In recent times, corrosion has been controlled by deposition of a dense protective coating on ordinary boiler components as an alternative solution [10, 11-13]. However, there are several technical challenges in producing coatings that are able to meet high-performance requirements. Thermal spray coatings processed by conventional methods, e.g. high velocity oxy-fuel (HVOF) [1314], or atmospheric plasma spraying (APS) [16] have their own unique lamellar structures, and some in flight oxidation of the sprayed particles and certain process-dependent pore content is inevitable, making them less attractive for highly aggressive environments [17]. In comparison, coatings produced by the high velocity air-fuel (HVAF) method can be characterized by a relatively denser microstructure with less amount of oxides than the above thermal spray methods [18]. Although even the HVAF coatings are not entirely free from pores either [19], [20], among the above-mentioned processes, HVAF has the lowest flame temperature and highest flame velocity $\left(\mathrm{T}<1800^{\circ} \mathrm{C}, \mathrm{V}=700-1500 \mathrm{~m} / \mathrm{s}\right)$ [21]. These significantly affect the microstructural features, in particular in situ oxide formation, splat morphology, and porosity that can potentially enhance the level of protection imparted by these coatings and their corrosion behaviour [22].

Apart from the microstructure, the coating composition also plays a critical role in chlorine-induced corrosion protection [11], [14]. Ni-based coatings with addition of $\mathrm{Cr} / \mathrm{Al}$ have demonstrated high temperature corrosion protection and have been studied both in commercial boilers and in laboratory furnaces with simulated chlorine-containing environments [23], [24]. Although severely reduced, the corrosive agents have been found to be able to diffuse through some of the coatings, accompanied by depletion of protective scale-forming elements such as $\mathrm{Cr}$ or/and $\mathrm{Al}$ [25]. Unfortunately, only limited reported studies have compared the resistance of different coating chemistries subjected to identical test conditions. In addition, it is still unclear how $\mathrm{Cl}$ is able to diffuse (whether as $\mathrm{Cl}_{2}$ through the oxide pores and cracks or as $\mathrm{Cl}^{-}$through the oxide grain boundaries) and how the presence of metal chlorides accelerates corrosion in the complex chemistry of the thermally sprayed coatings. Understanding corrosion mechanisms in such heterogeneous coatings and identifying pathways to control it is of crucial importance for the development of coatings that are highly protective in aggressive working environments.

In this study, the primary aim was to investigate the ability of the HVAF coatings prepared from Nibased materials with varying scale-forming ability to protect boiler components in chlorine-laden environments. A key objective of the study was also to understand the mechanism associated with $\mathrm{Cl}$ interacting at high temperature with two Ni-based chromia and alumina forming coatings - Ni21Cr and Ni5Al. In order to get a better understanding of the complex corrosion reactions that occur during field exposures such as in biomass boilers, the laboratory exposure was performed in a simulated environment, with the isothermal oxidation performance of the coatings being investigated in $5 \% \mathrm{O}_{2}+$ 
500 vppm $\mathrm{HCl}+\mathrm{N}_{2}$ bal. environment with and without $\mathrm{KCl}$ at $600^{\circ} \mathrm{C}$ for up to $168 \mathrm{~h}$. The results of more complex laboratory exposures mimicking the actual boiler environment which are currently being undertaken will be reported in a separate paper.

\section{Experimental procedure}

\subsection{Materials}

\subsubsection{Substrate material}

A commercially available low carbon steel $16 \mathrm{Mo} 3$ (nominal composition in wt $\%$; $0.01 \mathrm{Cr}-0.3 \mathrm{Mo}-0.5$ Mn- 0.3Si- 0.15C- Fe bal.) was used as substrate material. The composition was confirmed for all elements except carbon during the course of this study using X-ray energy dispersive spectroscopy (EDS). The geometry of the specimens used for investigations was buttons of $25 \mathrm{~mm}$ diameter and 5 mm thickness.

\subsubsection{Feedstock powders}

Two commercially available gas-atomized powders, $\mathrm{NiCr}$ (in wt $\%$; $78.6 \mathrm{Ni}-21.3 \mathrm{Cr}-0.1 \mathrm{O}$ ) and NiAl (in wt\%; $94.1 \mathrm{Ni}-5.7 \mathrm{Al}-0.2 \mathrm{O}$ ), with particle size of $45 \pm 22 \mu \mathrm{m}$ sourced by HC Starck GmbH (Germany) were used as feedstock powders.

\subsection{HVAF spraying}

A HVAF gun (Uniquecoat M3 ${ }^{\mathrm{TM}}$, Oilville, VA, USA) was used for depositing coatings and thermal spray conditions set accordingly. The $16 \mathrm{Mo} 3$ rod (length=500 mm) was fixed in a horizontal rotating mandrel and first a coating was applied on the cylindrical surface. The rod was then sliced into buttons of $5 \mathrm{~mm}$ thickness and both flat surfaces of the buttons were then HVAF sprayed so that the specimens were coated on all sides. Prior to spraying, the substrates specimens were grit blasted with alumina particles $(63 \pm 10 \mu \mathrm{m})$ for roughening and cleaning the surfaces to be coated. The HVAF spray parameters given in Table 1 were chosen based on preliminary coating trials conducted to obtain the least porous microstructure. All coatings were sprayed to a thickness of around $250 \mu \mathrm{m}$. Prior to the corrosion tests, all surfaces of the investigated samples were polished with a $0.2 \mu \mathrm{m} \mathrm{SiC}$ suspension to achieve a uniform surface roughness $\left(R_{a}<0.1 \mu \mathrm{m}\right)$ on the coated specimens.

\subsection{Chlorine-induced corrosion test}

The corrosion tests were performed in 5 vol. $\% \mathrm{O}_{2}+500 \mathrm{vppm} \mathrm{HCl}+\mathrm{N}_{2}$ at $600 \pm 1{ }^{\circ} \mathrm{C}$ in time steps of 24, 96 and $168 \mathrm{~h}$ with and without $\mathrm{KCl}$ salt deposit. The set-up comprised a horizontal tube furnace with a stainless steel vessel and the inside of the chamber was entirely lined with high purity alumina. A mass flow controller was used to introduce $35 \mathrm{~cm}^{3} / \mathrm{min}$ of gas composed of $5 \% \mathrm{O}_{2}-500 \mathrm{vppm} \mathrm{HCl}-\mathrm{N}_{2}$ through the chamber during the test. A flow of $\mathrm{N}_{2}$ was also maintained to avoid any corrosion during cooling. The aim of selecting $\mathrm{HCl}(\mathrm{g})$ and $\mathrm{KCl}(\mathrm{s})$ as corrosive species, based on earlier studies [26], was 
to investigate coating behaviour in two distinct environments, corresponding to predominant gas phase and solid salt rich in $\mathrm{Cl}$. The exposures were performed using a step-wise approach as described below; A KCl suspension was prepared with ethanol, and the deposit $\left(\sim 0.1 \mathrm{mg} / \mathrm{cm}^{2}\right)$ was applied on the surface of the sample using a paintbrush. The samples were then placed in individual alumina crucibles. Just before the test, each sample and each crucible were individually weighed using a Sartorius ${ }^{\mathrm{TM}}$ balance (Cubis MSA3.6P0TRDM, Sartorius, Germany) with microgram resolution. The crucible and sample with deposit were also weighed together to calculate the exact amount of deposit placed on the sample. After the test, the samples were extracted from the furnace, weighed in their individual crucibles together with the oxide scale spalled from the exposed material. Later, the individual samples were also weighed alone without the crucible. The balance was calibrated frequently using its internal calibration function and periodically with standard weights. Although necessary precaution was taken during each measurement, sintering of $\mathrm{KCl}$ formed on top of the coatings at high temperature might reduce the accuracy of the measurements.

\subsection{Characterization of coatings}

To observe the surface morphology of the as-sprayed and exposed coatings, the specimens were placed onto carbon stubs and examined using a scanning electron microscope (SEM). To analyse the cross sections, the as-sprayed coatings were cut using a diamond tipped precision saw and then cold mounted in a low shrinkage resin to prevent spallation of the formed oxide scale. The mounted samples were ground/polished to a $0.2 \mu \mathrm{m}$ colloidal silica finish. The cross-section and surface morphology of all assprayed and exposed coatings was characterized using a QUANTA-200 FEG (FEI, Oregon, USA) SEM equipped with X-ray energy dispersive spectroscopy (EDS). The topographic features of the polished coatings were analysed using a secondary electron (SE) detector, whereas the cross-sections of the exposed coatings were studied using backscattered electron (BSE) signals. An accelerating voltage of $20 \mathrm{kV}$ in BSE and $10 \mathrm{kV}$ in SE mode was used for the SEM analysis in order to improve the spatial resolution. The phases present in the coating before and after the oxidation tests were identified by a D5000 X-ray diffractometer (XRD) (Siemens, Germany), equipped for grazing incidence analysis with $\mathrm{Cu}-\mathrm{K}_{\alpha}$ radiation $(\lambda=0.154 \mathrm{~nm})$ operating with a fixed incident angle of $1^{\circ}$ and diffraction angle $(2 \theta)$ between $25^{\circ}$ and $80^{\circ}$. Before the XRD measurement, a calibration sample ( $\left.\mathrm{LaB}_{6}\right)$ was used to avoid peak broadening due to instrumental parameters, e.g. collimator size, detector resolution and beam divergence. The extent of porosity was determined by image analysis (IA) technique using ImageJ software [27] by converting the SEM micrographs of the polished coatings with horizontal field width of $100 \mu \mathrm{m}$ into binary images, and quantifying the percentages based on the grey scale contrast [19]. The surface roughness $\left(R_{a}\right)$ of the coatings was measured using a stylus-based profilometer (Surftest 301, Mitutoyo, Japan). Three measurements in three different directions were performed and the measured values were averaged. 
2.5 Phase stability modelling

Stability diagrams of the coating elements were plotted using the HSC 6.0 software to correlate experimental observations and thermodynamic calculations in different $\mathrm{O}_{2}$ and $\mathrm{Cl}_{2}$ partial pressures at $600{ }^{\circ} \mathrm{C}$.

\section{Results}

3.1 Microstructure of as-sprayed coatings

Fig. 1 shows the microstructure of the $\mathrm{NiCr}$ and $\mathrm{NiAl}$ coatings in cross-section. Both microstructures revealed substantially dense coatings, with negligible pores and oxides at splat boundaries. From the high-magnification SEM micrographs, the splat boundaries could be clearly detected. A few particles that were either semi-molten or not fully plastically deformed to form splats were also noted. Fig. 1 shows well-bonded coatings, with no visible separation between the coatings and substrates. The porosity measured on the cross-sectional images using image analysis method was $0.5 \pm 0.1$ and $0.3 \pm$ 0.1 vol.\% for $\mathrm{NiCr}$ and $\mathrm{NiAl}$, respectively.

Some intrinsic features such as splat boundaries around insufficiently plastically deformed particles as well as pores could be readily characterized on top surface of the polished coatings (See Fig. 2). The plastic deformation of particles in case of the $\mathrm{NiAl}$ coating appeared more complete as less semi-molten particles (or near round particles) were observed on the NiAl coatings' surface.

\subsection{Phase constitution of coatings}

The XRD patterns of feedstock powders and polished coatings are shown in Fig. 3. Three primary peaks of the powders $\left(2 \theta\left(^{\circ}\right) \approx 43.5,51\right.$, and 75$)$ corresponded to the austenitic $\mathrm{Ni}-(\mathrm{Cr} / \mathrm{Al})$ solid solution phase. The polished coatings retained the solid solution phase of the feedstock powders. Slight shift of the position of the peaks and significant broadening of the main peaks was observed in the coatings compared to that of the feedstock powder.

\subsection{Corrosion of exposed coatings}

Fig. 4 shows the weight change of $\mathrm{NiCr}$ and $\mathrm{NiAl}$ coatings exposed at $600{ }^{\circ} \mathrm{C}$ for up to $168 \mathrm{~h}$, with and without $\mathrm{KCl}$ deposit. It should be noted that due to $\mathrm{KCl}$ left sintered on the coatings, the weight gain exclusively attributable to corrosion could not be precisely evaluated from the weight measurements. However, evident correlation between the weight gain and coatings' chemistry as well as the presence of $\mathrm{KCl}$ could be clearly observed.

The weight gain of both coatings generally followed an identical trend, both with and without $\mathrm{KCl}$. The weight rapidly increased during the early stages and the rate of weight gain reduced as the exposure time increased. The weight of the $\mathrm{NiCr}$ coating exposed to $\mathrm{KCl}$ indeed showed a drop in weight from $96 \mathrm{~h}$ to $168 \mathrm{~h}$. The results showed that a higher weight gain was recorded in the presence of $\mathrm{KCl}$ deposit for both coatings, which reflected the substantial contribution of $\mathrm{KCl}$ to the corrosion damage. The 
weight change in $\mathrm{NiCr}$ and $\mathrm{NiAl}$ coatings exposed to $600 \mathrm{C}$ for $168 \mathrm{~h}$ without $\mathrm{KCl}$ deposit was 0.5 $( \pm 0.03)$ and $0.45( \pm 0.02) \mathrm{mg} / \mathrm{cm}^{2}$, respectively, whereas the recorded values increased substantially to $11.32( \pm 0.57)$ and $2.49( \pm 0.12) \mathrm{mg} / \mathrm{cm}^{2}$, respectively, in the presence of $\mathrm{KCl}$. The results confirmed that that the $\mathrm{NiCr}$ coating with $\mathrm{KCl}$ underwent the most severe corrosion.

\subsection{Surface characteristics of the oxide layer}

Corrosion products with different colours could be easily detected by visual inspection of the coatings after the exposure tests (see Fig. 5). It is clear that the $\mathrm{NiCr}$ coating with $\mathrm{KCl}$ underwent the most severe damage, whereas the $\mathrm{NiAl}$ coating without $\mathrm{KCl}$ showed the least damage. The appearance of NiAl coatings was almost the same with and without $\mathrm{KCl}$, whereas a yellowish-green corrosion product was noted on the $\mathrm{NiCr}$ coating under the $\mathrm{KCl}$ deposit. The yellow product is plausibly potassium chromate $\left(\mathrm{K}_{2} \mathrm{CrO}_{4}\right)$, while the green product, that apparently locally varied in thickness, could be a mixed oxide scale including non-protective $\mathrm{Cr}_{2} \mathrm{O}_{3}$ or $\mathrm{NiCr}_{2} \mathrm{O}_{4}$ [28], as both confirmed later confirmed through EDS/SEM/XRD analysis.

According to the XRD analysis shown in Fig. 6 and the corresponding topographic micrographs shown in Fig. 7 (a-b), a mixed layer of spinel-type oxide corresponding to $\mathrm{NiCr}_{2} \mathrm{O}_{4}$, along with $\mathrm{K}_{2} \mathrm{CrO}_{4}$, and $\mathrm{KCl}$, formed on the surface of $\mathrm{NiCr}$ in the presence of $\mathrm{KCl}$. The $\mathrm{NiCr}$ coating exposed in the absence of $\mathrm{KCl}$ only formed $\mathrm{Cr}_{2} \mathrm{O}_{3}$ and $\mathrm{NiCr}_{2} \mathrm{O}_{4}$.

The thickness of the corrosion product was very thin on $\mathrm{NiAl}$, both in the presence and in the absence of $\mathrm{KCl}$ since the primary phases of the coatings $(\mathrm{Ni}, \mathrm{NiAl})$ were detected after the exposure in both

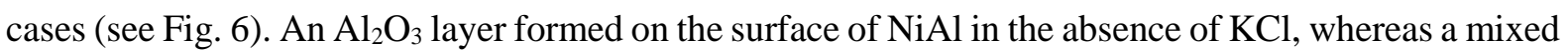
layer of $\mathrm{Al}_{2} \mathrm{O}_{3}$ and $\mathrm{NiAl}_{2} \mathrm{O}_{4}$ was detected on $\mathrm{NiAl}$ under the $\mathrm{KCl}$ deposit. A small amount of $\mathrm{KCl}$ observed on NiCr in Fig. 6, could not be detected on NiAl in Fig. 6 as it was probably under the identification limit of XRD in the latter.

As can be seen in Fig. 7 (a-b), an oxide scale comprising $\mathrm{Cr}_{2} \mathrm{O}_{3}$ and $\mathrm{NiCr}_{2} \mathrm{O}_{4}$ was formed on $\mathrm{NiCr}$ in the absence of $\mathrm{KCl}$ (Fig. 7a), whereas numerous small particles (up to $\sim 2 \mu \mathrm{m}$ in size) identified as $\mathrm{K}_{2} \mathrm{CrO}_{4}$ (confirmed by XRD and SEM/EDS), $\mathrm{Cr}_{2} \mathrm{O}_{3}$ and $\mathrm{NiCr}_{2} \mathrm{O}_{4}$ formed on the surface of NiCr exposed to $\mathrm{KCl}$ (Fig. 7b). The $\mathrm{K}_{2} \mathrm{CrO}_{4}$ particles aggregated in a characteristic way forming circular patterns (Fig. $7 b$ ), showing $\mathrm{K}_{2} \mathrm{CrO}_{4}$ particles on top of a smooth base oxide. This pattern may reflect the initial distribution of $\mathrm{KCl}$ on the surface, which resulted from the HVAF spraying procedure. After the exposure, no unreacted $\mathrm{KCl}$ remained on the surface of the $\mathrm{NiCr}$ coating. Fig. 7 (c-d) shows the topography of $\mathrm{NiAl}$ with and without $\mathrm{KCl}$. While in the absence of $\mathrm{KCl}, \mathrm{Al}_{2} \mathrm{O}_{3}$ mostly covered the surface, in the presence of $\mathrm{KCl}$, the oxide locally spalled off and the splats and splat boundaries became visible.

3.5 Microstructure of formed oxide scales

\subsubsection{NiCr without $\mathrm{KCl}$}


As can be seen in Fig. 8, no trace of internal oxide through splats or splat boundaries could be observed in the absence of $\mathrm{KCl}$, confirming that $\mathrm{HCl}$ alone could not significantly damage the coating. Fig. 8 reveals a protective and thin layer of oxide remaining intact on the surface of the $\mathrm{NiCr}$ coating even after exposure. Based on the EDS point and elemental mapping analysis of the formed oxide scale and the XRD results, an oxide scale consisting of a continuous layer of $\mathrm{Cr}$-rich oxide $\left(\mathrm{Cr}_{2} \mathrm{O}_{3}\right)$ and some $\mathrm{NiCr}_{2} \mathrm{O}_{4}$ could be identified on the surface. The EDS analysis showed some variations in the chemical composition of the formed oxide scales. The oxide layer had a $\mathrm{Cr}$ content of about 46 and $56 \mathrm{wt} \%$ in spots 1 and 2, respectively, confirming formation of the two mentioned oxides. Formation of the oxide scale led to creation of a Cr-depletion zone, as seen in Cr EDS mapping in Fig. 8.

Fig. 9a shows the EDS point analysis in the vicinity of a pore in the middle of the $\mathrm{NiCr}$ coating after the exposure. As no obvious sign of $\mathrm{Cl}$ was detected at splat boundaries (spots 1-5) and inside the splats (spot 6), most probably no $\mathrm{Cl}$ diffusion through the coating occurred. The $\mathrm{Cr}$ content was almost the same for all spots around the pore (spots 1-4), whereas it was higher for spot 5 which was slightly away from the pore but within a clear splat boundary. The latter could be attributed to presence of chromium oxide at the splat boundary, as also suggested by the slightly higher $\mathrm{O}$ content at this location.

Fig. $9 \mathrm{~b}$ shows the EDS point analysis in the region close to the coating/substrate interface. Spots 1 and 2, (both belonging to the substrate), showed the level of $\mathrm{Ni}$ and $\mathrm{Cr}$ inter-diffusion from the coating towards the substrate after the exposure. A high level of Fe was also detected near to the interface in spot 3 , while it lowered in spot 4 which was around $15 \mu \mathrm{m}$ away from the interface. No trace of $\mathrm{Cl}$ was detected adjacent to the interface either in the splat (spot 3), or at the splat boundaries (spot 4).

\subsection{2 $\mathrm{NiCr}$ with $\mathrm{KCl}$}

Fig. 10 (a-b) presents the cross section of the $\mathrm{NiCr}$ coating after exposure in the presence of $\mathrm{KCl}$, showing a mixed oxide scale/ layer with a thickness of $\sim 20 \mu \mathrm{m}$ on the coating surface. It can be clearly observed that a thickness of $\sim 120 \mu \mathrm{m}$ of the coating (from its top surface) was affected by the presence of $\mathrm{KCl}$. This type of degradation was not observed in $\mathrm{NiCr}$ without $\mathrm{KCl}$ discussed in Section 3.5.1. EDS elemental mapping analysis detected signals from $\mathrm{Cr}, \mathrm{O}, \mathrm{Cl}, \mathrm{Ni}$ and $\mathrm{K}$ in the mixed oxide scale/deposit layer. The simultaneous presence of $\mathrm{K}$ and $\mathrm{Cr}$ was mainly restricted to the top of the coating (Fig. 10b), thereby suggesting that $\mathrm{K}$ participated in the chemical reactions. The $\mathrm{K}$ - and $\mathrm{Cr}$-rich particles were considered to be $\mathrm{K}_{2} \mathrm{CrO}_{4}$ along with $\mathrm{KCl}$ (see XRD analysis in Fig. 6). The EDS maps showed that some of the reacted $\mathrm{K}$ could also be associated with $\mathrm{Cl}$. Beneath the $\mathrm{K}_{2} \mathrm{CrO}_{4}$ layer, local depletion of $\mathrm{Cr}$ along with $\mathrm{Ni}$ enrichment was visible.

A magnified view of the formed oxide layers is presented in Fig. 10b showing formation of a mixed oxide on top and $\mathrm{NiCr}_{2} \mathrm{O}_{4} / \mathrm{Cr}_{2} \mathrm{O}_{3}$ layers beneath. While the top layer was porous, the layer consisting of $\mathrm{NiCr}_{2} \mathrm{O}_{4} / \mathrm{Cr}_{2} \mathrm{O}_{3}$ had a thickness of approx. 3-5 $\mu \mathrm{m}$, and was dense and adherent to the coating. Cr was enriched in three distinct layers: one within the mixed oxide layer, one above the coating and another in the splat boundaries. Based on the EDS point analysis in Fig. 10b, along with sintered $\mathrm{KCl}, \mathrm{K}_{2} \mathrm{CrO}_{4}$ 
most probably formed on top of the oxide scale due to high presence of $\mathrm{O}, \mathrm{K}$ and $\mathrm{Cr}$ verified in spot 1 , whereas spots 2 to 5 confirmed formation of Ni-rich oxide scale due to the higher presence of $\mathrm{Ni}$. An inner Cr-rich oxide layer just below the outer Ni-rich could be observed in Fig. 10b. A Cr-depletion zone below the formed oxide scale was also detected (spot 7). Based on the EDS point analysis, chlorine was detected close to or at the oxide/coating interface.

As can be seen in Fig. 11a, in the middle of the $\mathrm{NiCr}$ coating, $\mathrm{Cl}$ was found around unmelted particles rather than inside the coating's particles confirming preferential $\mathrm{Cl}$ diffusion through the boundaries. High $\mathrm{Cr}$ depletion could be detected within the particles, where $\mathrm{Cr}$ diffused towards the boundaries to form the oxide layer.

Fig. 11b shows formation of a Cr-rich phase between the substrate and coating, most probably attributed to $\mathrm{NiCr}_{2} \mathrm{O}_{4}$. A high amount of $\mathrm{Cl}$ (spot 1), along with formation of voids within the substrate was observed. Spots 4 and 6 could verify that $\mathrm{Cl}$, evidently sourced from $\mathrm{KCl}$, could diffuse through the splat boundaries and reach the substrate and not through the splats (spot 5). High amount of $\mathrm{Cl}$ and $\mathrm{O}$ detected in the substrate in spot 1 denoted that the substrate was also damaged by $\mathrm{Cl}$.

\subsubsection{NiAl without $\mathrm{KCl}$}

As seen in Fig. 12, the coating microstructure seems to be unaffected by the chloridizing-oxidizing test environment. Moreover, a 1- $\mu \mathrm{m}$ thin continuous layer of oxide scale entirely formed on the surface of the NiAl coating in the absence of $\mathrm{KCl}$. No $\mathrm{Cl}$ was detected within the coating, confirming the high corrosion protection provided by the formed oxide scale. The coating microstructure was almost unaffected after the exposure. The oxide scale formed on NiAl showed a similar thickness as that formed on the NiCr sample in Fig. 10b. However, the formed $\mathrm{Al}_{2} \mathrm{O}_{3}$ scale on $\mathrm{NiAl}$ is more uniform without any degradation within the splat boundaries, unlike that observed in case of $\mathrm{NiCr}$ in Fig. 10b.

\subsubsection{NiAl with $\mathrm{KCl}$}

The morphology of the corrosion products formed on the NiAl-KCl coating (Fig. 13) was similar to that without $\mathrm{KCl}$. A thin oxide layer rich in $\mathrm{Al}$ covered the entire coating surface, however some interruptions within the layer could be seen in $\mathrm{Al}$ signals in EDS elemental mapping analysis. Some signs of $\mathrm{Al}_{2} \mathrm{O}_{3}$ were observed within the coating, attributed to formation of $\mathrm{Al}_{2} \mathrm{O}_{3}$ within the splat boundaries.

Fig. 13 shows that the thickness of the oxide layer was $\sim 2 \mu \mathrm{m}$. Some unreacted $\mathrm{KCl}$, which was not detected in XRD patterns in Fig. 6, could be identified on top of the coating confirmed by EDS analysis of spot 1. Spot 2 confirmed that the formed oxide layer was rich in $\mathrm{Ni}$ and Al. A coating composition similar to the composition of the as-sprayed NiAl coating at spot 3 denoted negligible diffusion of $\mathrm{Cl}$ through the splats.

\section{Discussion}


4.1 Microstructure of as-sprayed coatings

The coating with a high corrosion resistance demands a dense microstructure, high adhesion to the substrate and absence of interconnected pores, which might serve as diffusion paths for the corrosive agents [23]. The experimental results in Fig. 1 showed that the dense and adherent $\mathrm{NiCr}$ and $\mathrm{NiAl}$ coatings sprayed by HVAF could be good candidates for corrosion protection applications. The protective scale forming elements such as $\mathrm{Cr}$ or/and $\mathrm{Al}$ are not depleted during the spraying process but preserved for oxidation protection (see EDS point analysis in Fig. 1). This is a consequence of the negligible in situ oxide pick up or phase transformation during HVAF spraying.

The XRD patterns of the as-sprayed coatings (Fig. 3) showed that the Ni peaks shifted towards shorter lattice parameters (higher $2 \theta$ angles) which might be due to the level of residual stresses within the coatings (macrostrain) [15]. The peak broadening of the as-sprayed coatings compared to the powders is due to three primary factors of a) presence of micro-strain due to the plastic deformation during the HVAF spraying process [29], b) reduction in crystallite size, and c) instrumental broadening due to beam size, sample to detector distance, air scatter, etc. [30]. While the level of micro-strain can be studied using a line profile analysis, numerous methods have been developed to quantify the crystal size and residual strain, which is not under the scope of this study.

The XRD results proved that the HVAF process did not affect the phase composition of the feedstock powders. Formation of few in situ oxides could likely be due to; a) the powder particles being exposed to high temperature in oxidizing ambient air environment during the spraying process [30-31] and/or b) because of pre-existing oxygen in the feedstock material [32]. The influence of the former is minimal in the investigated samples, as the dwell time in the HVAF process is small and the temperature is also very low [19].

\subsection{Chlorine-induced corrosion in coatings}

It is well known that the oxidation resistance of $\mathrm{Al} / \mathrm{Cr}$-bearing alloys depends on formation of a protective $\mathrm{Al}_{2} \mathrm{O}_{3} / \mathrm{Cr}_{2} \mathrm{O}_{3}$ layer via a selective oxidation process [23]. This requires that the $\mathrm{Al} / \mathrm{Cr}$ concentration in the alloys exceed a critical value. In cast $\mathrm{NiAl}$ and $\mathrm{NiCr}$ alloys, a composition with $>17 \mathrm{wt} \% \mathrm{Al}$ and $>20 \mathrm{wt} \% \mathrm{Cr}$, respectively [33], is usually needed to suppress internal oxidation and/or the rapid growth of non-protective surface oxides. The critical concentration may vary depending on some other factors, including microstructure, surface working states, working temperature and duration, environmental condition and other alloying elements [34]. The case becomes more complex in case of coatings, since inherent features such as splat boundaries, pores and in situ formed oxides influence the corrosion process and must be also considered [24]. Formation of a protective oxide scale can also be promoted by increasing the uniformity of the coatings in terms of the microstructure and composition which could serve as a reservoir, to maintain a continued exclusive growth of the protective oxide scale [21]. 
The weight change data shown in Fig. 4 confirmed the better corrosion performance of the $\mathrm{Al}_{2} \mathrm{O}_{3}$ forming $\mathrm{NiAl}$ coating than that of the $\mathrm{Cr}_{2} \mathrm{O}_{3}$-forming $\mathrm{NiCr}$ coating, in particular with $\mathrm{KCl}$. The lower oxide scale growth of the $\mathrm{NiAl}$ coating compared to the $\mathrm{NiCr}$ sample explained the better corrosion performance of $\mathrm{NiAl}$. The high weight gain for the $\mathrm{NiCr}-\mathrm{KCl}$ sample could be due to a combination of various reasons; a) deterioration of the substrate (16Mo3) by $\mathrm{Cl}$, see Fig. 11b, b) sintering of $\mathrm{KCl}$ on the surface during the exposure, see Fig. 10 in agreement with the literature [35], and c) formation of metallic chlorides, mainly $\mathrm{CrCl}_{3}$ (s) or $\mathrm{CrCl}_{2}$ (s) within the coating, see Fig. 11a. The decrease in weight during the final stage could be due to evaporation of such metallic chlorides [2]. It is worth noting that the $\mathrm{NiCr}$ coating with $\mathrm{KCl}$ presented the highest standard deviation in the weight measurement values. Generally, there could be several sources for such a deviation, i.e. non-uniformity in the coating's composition, inhomogeneous microstructure, corrosion product thickness or test atmosphere [36]. Although the first two reasons are less plausible in case of HVAF coatings, it has been reported that irregularities in corrosion product thickness can lead to localized corrosion or, even worse, to internal degradation [37]. In view of the above, the intensity of local corrosion attack can vary, resulting in formation of oxide layer of variable thickness.

\subsubsection{NiCr coating}

As very little $\mathrm{Cl}$ at the oxide/ $\mathrm{NiCr}$ coating interface and large amounts of $\mathrm{K}$ were present (far away from $\mathrm{Cl}$ ) throughout the scale after the exposure (see Fig. 10), it could be proposed that corrosion was initiated by the reaction of $\mathrm{KCl}$ with $\mathrm{Cr}_{2} \mathrm{O}_{3}$ in the scale, forming $\mathrm{K}_{2} \mathrm{CrO}_{4}$ and $\mathrm{Cl}^{-}$based on Eqs. (3-8). Formation of $\mathrm{K}_{2} \mathrm{CrO}_{4}$ was probably because of the higher oxygen availability at the salt deposit boundaries.

While degradation of the protective oxide layer can be attributed to formation of $\mathrm{K}_{2} \mathrm{CrO}_{4}$ at the beginning of exposure, it was observed by Israelsson et al. and Shu et al. [35], [38] that instead of $\mathrm{Cl}_{2}$ (proposed in the chlorine-active corrosion mechanism), $\mathrm{Cl}^{-}$could penetrate the oxide scale through the grain boundaries, leading to failure (with time) of the protective oxide layer. $\mathrm{Cl}$ was detected within the NiCr coating's splat boundaries (see Fig. 11a), where oxide was also available. As already mentioned, reaction proposed in the chlorine-active corrosion mechanism is not thermodynamically favoured (see $\Delta \mathrm{G}^{\circ}$ in Eq. 1) and $\mathrm{Cl}_{2}$ penetration through the scale is not explained well. It could be proposed that $\mathrm{Cl}^{-}$ could diffuse through the oxide scale and coating via the grain boundaries and splat boundaries, respectively, where the oxide is available. As $\mathrm{Cl}^{-}$is smaller than $\mathrm{Cl}_{2}$, it has higher mobility in the grain boundary region of an oxide. Once $\mathrm{Cl}^{-}$reaches the scale/coating interface, it reacts with transition metal ions formed by the oxidation of coating (see Eq. 3) [7]. It should be noted that the scale/coating interfaces could exist either on top of the coating or at the splat boundaries where oxide is able to form.

Scale/coating interface:

$\mathrm{Cr}=\mathrm{Cr}^{2+}($ oxide $)+2 e^{-}$ 
Scale surface:

$\frac{1}{2} \mathrm{Cr}_{2} \mathrm{O}_{3}+4 \mathrm{KCl}(s)+\frac{5}{2} \mathrm{O}_{2}(g)+2 e^{-} \rightarrow \mathrm{K}_{2} \mathrm{CrO}_{4}(s)+2 \mathrm{Cl}^{-}$

at the locations where $\mathrm{Cl}^{-}$and $\mathrm{Cr}^{2+}$ meet each other within the coating:

$\mathrm{Cr}^{2+}+\mathrm{Cl}^{-}=\mathrm{CrCl}_{2}(\mathrm{~s})$

$\mathrm{CrCl}_{2}(s)=\mathrm{CrCl}_{2}(g)$

The sum reaction becomes (for the case of Cr oxidation):

$$
\begin{aligned}
& \frac{1}{2} \mathrm{Cr}_{2} \mathrm{O}_{3}+2 \mathrm{KCl}(s)+\frac{5}{4} \mathrm{O}_{2}(\mathrm{~g})+\mathrm{Cr} \rightarrow \mathrm{K}_{2} \mathrm{CrO}_{4}(\mathrm{~s})+\mathrm{CrCl}_{2}(\mathrm{~g}) \\
& \Delta G_{f}^{0}\left(\mathrm{~K}_{2} \mathrm{CrO}_{4}\right) \approx-97.9 \mathrm{~kJ} / \mathrm{mol} \text { at } 600{ }^{\circ} \mathrm{C} \\
& \frac{1}{3} \mathrm{Cr}_{2} \mathrm{O}_{3}+2 \mathrm{KCl}(\mathrm{s})+\frac{3}{2} \mathrm{O}_{2}(\mathrm{~g})+\mathrm{Cr} \rightarrow \mathrm{K}_{2} \mathrm{CrO}_{4}(\mathrm{~s})+\frac{2}{3} \mathrm{CrCl}_{3}(\mathrm{~g}) \\
& \Delta G_{f}^{0}\left(\mathrm{~K}_{2} \mathrm{CrO}_{4}\right) \approx-292.6 \mathrm{~kJ} / \mathrm{mol} \text { at } 600{ }^{\circ} \mathrm{C}
\end{aligned}
$$

The formed solid chlorides have considerable equilibrium vapour pressures, evaporate readily, and diffuse upward towards gas-oxide scale interface. When the sufficient $p \mathrm{O}_{2}$ is available, the gaseous chlorides react with the available oxygen to form solid oxides, releasing gaseous chlorine, see Eqs. (910) [4], e.g.:

$$
\begin{array}{ll}
\mathrm{CrCl}_{3}(g)+\mathrm{O}_{2}(g) \rightarrow \frac{1}{2} \mathrm{Cr}_{2} \mathrm{O}_{3}(\mathrm{~s})+\mathrm{Cl}_{2}(g) & \Delta G_{f}^{0}\left(\mathrm{Cr}_{2} \mathrm{O}_{3}\right) \approx-127.8 \mathrm{~kJ} / \mathrm{mol} \mathrm{at} 600{ }^{\circ} \mathrm{C} \\
\mathrm{NiCl}_{2}(g)+\frac{1}{2} \mathrm{O}_{2}(g) \rightarrow \mathrm{NiO}(\mathrm{s})+\mathrm{Cl}_{2}(g) & \Delta G_{f}^{0}(\mathrm{NiO}) \approx-50.9 \mathrm{~kJ} / \mathrm{mol} \text { at } 600{ }^{\circ} \mathrm{C}
\end{array}
$$

The oxide scales formed through these reactions are rather porous, non-protective, and non-adherent to the coating, based on the results obtained in this study, and in agreement with the literature [34]. Independently of Eqs. (3-8) regarding formation of $\mathrm{Cl}^{-}$and the subsequent $\mathrm{Cl}^{-}$diffusion through the oxide grain boundaries, $\mathrm{Cl}_{2}$ formed in Eqs. (9-10) could also diffuse through defects (mainly pores and cracks) in the new formed oxide scale towards the coating-substrate interface (where $p \mathrm{O}_{2}$ was still low). Depending upon the available alloying elements in the coating which were $\mathrm{Ni}$, and $\mathrm{Cr}$ in the present study, solid metal chlorides which are thermodynamically stable could form after reacting with $\mathrm{Cl}_{2}$ (where $p \mathrm{O}_{2}$ was high) (see Eqs. 11-13). These reactions occur along with the reactions proposed before in Eqs. (3-8). Cr seems to be more preferably attacked than $\mathrm{Ni}$, as the formation of $\mathrm{CrCl}_{2}$ or $\mathrm{CrCl}_{3}$ has more negative Gibbs free energy than the formation of $\mathrm{NiCl}_{2}$ [39], see Eqs (11-13).

$$
\begin{array}{ll}
\mathrm{Ni}(\mathrm{s})+\mathrm{Cl}_{2}(\mathrm{~g}) \rightarrow \mathrm{NiCl}_{2}(\mathrm{~s}) & \Delta G_{f}^{0}\left(\mathrm{NiCl}_{2}\right) \approx-173.9 \mathrm{~kJ} / \mathrm{mol} \text { at } 600{ }^{\circ} \mathrm{C} \\
\mathrm{Cr}(\mathrm{s})+\mathrm{Cl}_{2}(\mathrm{~g}) \rightarrow \mathrm{CrCl}_{2}(\mathrm{~s}) & \Delta G_{f}^{0}\left(\mathrm{CrCl}_{2}\right) \approx-287.0 \mathrm{~kJ} / \mathrm{mol} \text { at } 600{ }^{\circ} \mathrm{C} \\
2 \mathrm{Cr}(\mathrm{s})+3 \mathrm{Cl}_{2}(\mathrm{~g}) \rightarrow 2 \mathrm{CrCl}_{3}(\mathrm{~s}) & \Delta G_{f}^{0}\left(\mathrm{CrCl}_{3}\right) \approx-371.6 \mathrm{~kJ} / \mathrm{mol} \mathrm{at} 600^{\circ} \mathrm{C}
\end{array}
$$


It can be hypothesised that while the $\mathrm{NiCr}$ coating was initially degraded via the electrochemical mechanism in the first stage, the chlorine-active corrosion mechanism along with the electrochemical mechanism contributed in the second stage of the coating's failure.

Regarding the conversion of the metal chlorides into metal oxides, $p \mathrm{O}_{2}$ for the different chloride/oxide reactions (all in bar: $6.46 \times 10^{-21}$ in $\mathrm{CrCl}_{2} / \mathrm{Cr}_{2} \mathrm{O}_{3}, 1.35 \times 10^{-17}$ in $\mathrm{CrCl}_{3} / \mathrm{Cr}_{2} \mathrm{O}_{3}$, and $2.20 \times 10^{-9}$ in $\mathrm{NiCl}_{2} / \mathrm{NiO}$ ) indicates the ease with which the reaction can proceed [40]. $\mathrm{NiO}$ needed the highest $p \mathrm{O}_{2}$ to be formed from the $\mathrm{NiCl}_{2}$, whereas $\mathrm{Cr}_{2} \mathrm{O}_{3}$ was more easily converted from $\mathrm{CrCl}_{2}$ and $\mathrm{CrCl}_{3}$ respectively at lower $p \mathrm{O}_{2}$. While $\mathrm{NiCl}_{2}$ (g) was most probably released in the atmosphere, $\mathrm{CrCl}_{2}$ or $\mathrm{CrCl}_{3}$ converted to $\mathrm{Cr}_{2} \mathrm{O}_{3}$, see the XRD results of the exposed samples in Fig. 6.

\subsubsection{NiAl coating}

In case of the NiAl coating, there was most probably no path for $\mathrm{Cl}^{-}$diffusion, as shown in the EDS analysis in Figs. 12 and 13, consistent with the literature [41]. The corrosion products on NiAl-KCl did not present a layered morphology of different oxides as seen in NiCr. A possible explanation might be that the formed oxide layer was continuous and protective enough on the coating surface to not allow high availability of $\mathrm{Cl}^{-}$and $\mathrm{O}_{2}$ already on the coating/oxide interface, so that the different metal chlorides could not oxidize together. It was reported that local failures and flaws like cracks, detachment and transient oxide (rather than the typical point and planar defects in a nonstoichiometric oxide like $\mathrm{Cr}_{2} \mathrm{O}_{3}$ ) need to be present in a protective alumina scale to favour the diffusion of the corrosive species [8]. As a result, the mechanism proposed here for the $\mathrm{NiCr}$ coating could not be initiated for the $\mathrm{NiAl}$ coating as the protective alumina scale acted as an effective barrier for the diffusion of ions (see Fig. 5). A negligible amount of $\mathrm{Cl}$ detected within the alumina layer in Fig. 13 might be attributed to the slight formation of $\mathrm{NiAl}_{2} \mathrm{O}_{4}$ along with the highly protective alumina scale. In agreement with the previous studies [42], $\mathrm{Al}_{2} \mathrm{O}_{3}$ scales showed better corrosion protection than $\mathrm{Cr}_{2} \mathrm{O}_{3}$ scales in chlorine environment.

\subsubsection{Phase stability diagram}

In Fig. 14, the phase stability diagram of the (Ni-Cr-Al)-O-Cl system is shown at $600{ }^{\circ} \mathrm{C}$ as a function of $p \mathrm{O}_{2}$ and $p \mathrm{Cl}_{2}$ using HSC 6.0 chemistry software [43]. The diagram combines values of the Gibbs free energy of formation and the vapour pressure of the metal chlorides. A good agreement was obtained between the results of the thermodynamic calculations and the experimental investigations under the present test conditions. Based on the diagram, the NiAl coating should be resistant to chlorine attack at $600{ }^{\circ} \mathrm{C}$ in the test condition (marked by a star). If $\mathrm{Cl}$ diffuses through the $\mathrm{Al}_{2} \mathrm{O}_{3}$ scale through the scales' flaws and reaches regions of low $p \mathrm{O}_{2}$ and high $p \mathrm{Cl}_{2}$, formation of volatile $\mathrm{AlCl}_{3}$ would be thermodynamically possible. However, $\mathrm{AlCl}_{3}(\mathrm{~g})$ evaporates and reaches the regions with high $p \mathrm{O}_{2}$ and quickly forms $\mathrm{Al}_{2} \mathrm{O}_{3}$ as suggested in Eq. 14. 
$\mathrm{AlCl}_{3}(g)+\frac{3}{4} \mathrm{O}_{2}(g) \rightarrow \frac{1}{2} \mathrm{Al}_{2} \mathrm{O}_{3}(\mathrm{~s})+\frac{3}{2} \mathrm{Cl}_{2}(g) \quad \Delta G_{f}^{0}\left(\mathrm{Al}_{2} \mathrm{O}_{3}\right) \approx-159.9 \mathrm{~kJ}$ at $600{ }^{\circ} \mathrm{C}$

Fig. 14 also shows that the atmosphere used in the experiments is clearly in the favour of formation of $\mathrm{Cr}_{2} \mathrm{O}_{3}$ and $\mathrm{Al}_{2} \mathrm{O}_{3}$ instead of $\mathrm{CrCl}_{3}, \mathrm{NiCl}_{2}$ and $\mathrm{AlCl}_{3}$ (see Eqs. 9 and 14). However, beneath the $\mathrm{KCl}$ deposit and especially at the oxide scale/coating interface or inside the coating, $p \mathrm{O}_{2}$ is low but $p \mathrm{Cl}_{2}$ is high, enabling other chlorides such as $\mathrm{CrCl}_{3}, \mathrm{CrCl}_{2}$, and $\mathrm{NiCl}_{3}$ to be thermodynamically stable. Formation of multiple oxide layers might help in increasing the gradient of $\mathrm{pO}_{2}$ from the corrosion front at the interface oxide/coating to the oxide/gas interface. Formation of different metal chlorides based on the reaction between $\mathrm{Cl}_{2}$ and the elements present in the coatings (Ni, and $\mathrm{Cr}$ ) (Eqs. 11-13) requires different values of $p \mathrm{O}_{2}$ for oxidation. As there is an oxygen gradient through the oxide scale, the metal chlorides oxidize at different distances from the corrosion front, when sufficient oxygen is available for oxidation reactions. The required $p \mathrm{O}_{2}$ is predictable using a stability diagram such as that presented in Fig. 14 for $\mathrm{Ni}, \mathrm{Cr}$, and $\mathrm{Al}$ (diagrams of (Ni-Cr-Al)-O-Cl)). The predominance diagram suggests that $\mathrm{NiO}$ could form further down from the coating/oxide interface, much away from where $\mathrm{Cr}$ would be able to form the corresponding oxides. On the other hand, $\mathrm{Cl}_{2}$ diffusion may advance deep through the coating's splat boundaries. Signs of $\mathrm{Cl}$ were readily detected from the EDS analysis on the cross sections at depth up to $120 \mu \mathrm{m}$ for the $\mathrm{NiCr}$ sample exposed to $\mathrm{KCl}$. At higher magnification (Fig. 10), some traces of $\mathrm{Cl}$ could be detected adjacent to the coating/substrate interface and even in the substrate. However, in the case of $\mathrm{NiAl}$ coating exposed to $\mathrm{KCl}$, as negligible $\mathrm{Cl}$ was detected in the coating's cross section, no significant changes in the coating's composition were observed far from the surface of the coating, where corrosion was the most severe (Fig. 13).

Based on the corrosion product layer thickness (Figs. 8, 10, 12, and 13) and the measured weight gains (Fig. 4), NiCr-KCl was more susceptible to corrosion than other samples, revealing higher overall corrosion product layer thickness and greater weight gain. In contrast, in a previous work [23] it was shown that in the absence of $\mathrm{HCl}$, the formed oxide scales were thinner $(1 \pm 0.23$ and $1 \pm 0.08 \mu \mathrm{m}$ for $\mathrm{NiAl}$ and $\mathrm{NiCr}$, respectively), and weight changes were lower for both coatings $(0.27 \pm 0.03$ and $0.37 \pm 0.05 \mathrm{mg} / \mathrm{cm}^{2}$ for $\mathrm{NiAl}$ and $\mathrm{NiCr}$, respectively), suggesting a lower corrosion rate in a pure oxidation environment rather than the gas phase chlorine-containing environment. In both environments with and without $\mathrm{HCl}$, the $\mathrm{Al}_{2} \mathrm{O}_{3}$-forming coating performed much better than $\mathrm{Cr}_{2} \mathrm{O}_{3}$-forming coating. It is worth noting that $\mathrm{HCl}(\mathrm{g})$ molecules do not diffuse through a $\mathrm{Cr}_{2} \mathrm{O}_{3}$ or $\mathrm{Al}_{2} \mathrm{O}_{3}$ scale, but $\mathrm{Cl}_{2}$ or $\mathrm{Cl}^{-}$ does [2]. However, no $\mathrm{Cl}$ diffusion through the $\mathrm{NiAl}$ and $\mathrm{NiCr}$ coatings in the absence of $\mathrm{KCl}$ was observed. The oxide layer formed in a chlorine atmosphere $(\mathrm{HCl})$ was more compact and most probably developed faster in the early stages of exposure, thus preventing $\mathrm{Cl}$ diffusion into the coating. However, in the presence of $\mathrm{KCl}$, the oxide layer developed on $\mathrm{NiCr}$ was thicker and, together with accompanying outward Cr diffusion (up to nearly total Cr depletion from the coating), had adverse effect on the coating resistance. The continuous and protective oxide layer formed on NiAl-KCl lasted until the end of 
exposure. The continuous surface oxide reduced the opportunity for the corrosive species to come in contact with the coating surface and thereby slowed down the oxidation rates that resulted in lower oxidation rates for the $\mathrm{NiAl}$ coating.

\section{Conclusions}

This work investigated the high temperature corrosion resistance of HVAF thermal-sprayed $\mathrm{NiCr}$ and $\mathrm{NiAl}$ coatings exposed to $5 \mathrm{vol} . \% \mathrm{O}_{2}+500 \mathrm{vppm} \mathrm{HCl}+\mathrm{N}_{2}$ with and without $\mathrm{KCl}$ salt deposit at 600 ${ }^{\circ} \mathrm{C}$ for up to $168 \mathrm{~h}$. The study aimed to better understand the effect of chlorine corrosion on the complex microstructure of the coatings and the main outcomes are summarized below:

(1) Both coatings performed well in the absence of $\mathrm{KCl}$ in controlling the corrosion of the substrate and acting as a barrier against the corrosive chlorine-containing environment. The oxidation behaviour was strongly dependent on the protective scale-forming elements such as $\mathrm{Cr}$ or/and $\mathrm{Al}$ in the coatings, which developed a protective $\mathrm{Al}_{2} \mathrm{O}_{3}$ or $\mathrm{Cr}_{2} \mathrm{O}_{3}$ scale at the test temperature.

(2) A two-stage mechanism was proposed for degradation of the $\mathrm{NiCr}$ coating, involving initial formation of $\mathrm{K}_{2} \mathrm{CrO}_{4}$ and $\mathrm{Cl}^{-}$through a reaction between $\mathrm{KCl}$ and $\mathrm{Cr}_{2} \mathrm{O}_{3}$ and the subsequent diffusion of the formed $\mathrm{Cl}_{2}$ inward through the defects and the oxide grain boundaries to reach the coating/oxide interface.

(3) The alumina scale formed on the NiAl coating was rather protective with $\mathrm{KCl}$. The protective alumina impeded the diffusion of $\mathrm{Cl}^{-}$in the first stage of the proposed mechanism.

(4) The interconnected porosity and splat boundaries act as paths for the $\mathrm{Cl}^{-} / \mathrm{Cl}_{2}$ diffusion as long as the oxide was present, and $\mathrm{Cl}^{-}$can diffuse through the splat boundaries of the coatings forming metal chlorides and accelerating corrosion, indicating that such regions were microstructural weak points controlling chlorine-induced corrosion.

\section{Acknowledgment}

Financial support of the Knowledge Foundation (DNR 20160201) is highly acknowledged. The authors would like to thank Mr. Jonas Olsson, Mr. Stefan Björklund, and Mr. Kenneth Andersson for their valuable help and advice in processing and characterization of the HVAF coatings in this study. The Swedish High Temperature Corrosion Centre (HTC) at Chalmers University of Technology is appreciated for the help in the XRD/SEM/EDS analysis.

\section{Reference}

[1] D. A. Tillman, 'Biomass cofiring: The technology, the experience, the combustion consequences', Biomass Bioenergy, vol. 19, no. 6, pp. 365-384, 2000.

[2] H. P. Nielsen, F. J. Frandsen, K. Dam-Johansen, and L. L. Baxter, 'Implications of chlorine-associated corrosion on the operation of biomass-fired boilers', Prog. Energy Combust. Sci., vol. 26, no. 3, pp. 283-298, 2000.

[3] Y. Y. Lee and M. J. McNallan, 'Ignition of nickel in environments containing oxygen and chlorine', Metall. Trans. Phys. Metall. Mater. Sci, vol. 18 A, no. 6, pp. 1099-1107, 1987.

[4] A. Zahs, M. Spiegel, and H. J. Grabke, 'Chloridation and oxidation of iron, chromium, nickel and their alloys in chloridizing and oxidizing atmospheres at $400-700^{\circ}$ C', Corros. Sci., vol. 42, no. 6, pp. 1093-1122, 2000. 
[5] C. Pettersson, J. Pettersson, H. Asteman, J.-E. Svensson, and L.-G. Johansson, 'KCl-induced high temperature corrosion of the austenitic $\mathrm{Fe}-\mathrm{Cr}-\mathrm{Ni}$ alloys $304 \mathrm{~L}$ and Sanicro 28 at $600^{\circ} \mathrm{C}^{\prime}$, Corros. Sci., vol. 48, no. 6, pp. 1368-1378, Jun. 2006.

[6] Y. Shinata, 'Accelerated oxidation rate of chromium induced by sodium chloride', Oxid. Met., vol. 27, no. 5-6, pp. 315-332, Jun. 1987.

[7] J. Pettersson, H. Asteman, J.-E. Svensson, and L.-G. Johansson, 'KCl Induced Corrosion of a 304-type Austenitic Stainless Steel at $600^{\circ} \mathrm{C}$; The Role of Potassium', Oxid. Met., vol. 64, no. 1-2, pp. 23-41, Aug. 2005.

[8] N. Israelsson, K. A. Unocic, K. Hellström, J.-E. Svensson, and L.-G. Johansson, 'Cyclic Corrosion and Chlorination of an FeCrAl Alloy in the Presence of KCl', Oxid. Met., vol. 84, no. 3-4, pp. 269-290, Oct. 2015.

[9] Y. Kawahara, "Application of high temperature corrosion-resistant materials and coatings under severe corrosive environment in waste-to-energy boilers', J. Therm. Spray Technol., vol. 16, no. 2, pp. 202-213, 2007.

[10] Y. S. Li, Y. Niu, and W. T. Wu, 'Accelerated corrosion of pure Fe, Ni,Cr and several Fe-based alloys induced by $\mathrm{ZnCl2-}$ $\mathrm{KCl}$ at $450{ }^{\circ} \mathrm{C}$ in oxidizing environment', Mater. Sci. Eng. A, vol. 345, no. 1-2, pp. 64-71, 2003.

[11] D. Fantozzi, V. Matikainen, M. Uusitalo, H. Koivuluoto, and P. Vuoristo, 'Chlorine-induced high temperature corrosion of Inconel 625 sprayed coatings deposited with different thermal spray techniques', Surf. Coat. Technol., vol. 318, pp. 233-243, May 2017.

[12] J. Zhou, J. K. Walleser, B. E. Meacham, and D. J. Branagan, 'Novel in situ transformable coating for elevatedtemperature applications', J. Therm. Spray Technol., vol. 19, no. 5, pp. 950-957, 2010.

[13] M. Oksa, S. Tuurna, and T. Varis, 'Increased Lifetime for Biomass and Waste to Energy Power Plant Boilers with HVOF Coatings: High Temperature Corrosion Testing Under Chlorine-Containing Molten Salt', J. Therm. Spray Technol., vol. 22, no. 5, pp. 783-796, Apr. 2013.

[14] M. Oksa, P. Auerkari, J. Salonen, and T. Varis, 'Nickel-based HVOF coatings promoting high temperature corrosion resistance of biomass-fired power plant boilers', Fuel Process. Technol., vol. 125, pp. 236-245, Sep. 2014.

[15] B. Song, Z. Pala, K. T. Voisey, and T. Hussain, 'Gas and liquid-fuelled HVOF spraying of Ni50Cr coating: Microstructure and high temperature oxidation', Surf. Coat. Technol., 2016.

[16] T. Hussain, T. Dudziak, N. J. Simms, and J. R. Nicholls, 'Fireside corrosion behavior of HVOF and plasma-sprayed coatings in advanced coal/biomass co-fired power plants', J. Therm. Spray Technol., vol. 22, no. 5, pp. 797-807, 2013.

[17] E. Sadeghimeresht, N. Markocsan, and P. Nylén, 'Microstructural characteristics and corrosion behavior of HVAF- and HVOF-sprayed Fe-based coatings', Surf. Coat. Technol., vol. 318, pp. 365-373, 2017.

[18] E. Sadeghimeresht, N. Markocsan, and P. Nylén, 'A Comparative Study on Ni-Based Coatings Prepared by HVAF, HVOF, and APS Methods for Corrosion Protection Applications', J. Therm. Spray Technol., vol. 25, no. 8, pp. 16041616, Dec. 2016.

[19] E. Sadeghimeresht, N. Markocsan, P. Nylén, and S. Björklund, 'Corrosion performance of bi-layer Ni/Cr2C3-NiCr HVAF thermal spray coating', Appl. Surf. Sci., vol. 369, pp. 470-481, Apr. 2016.

[20] E. Sadeghimeresht, N. Markocsan, and P. Nylén, 'Microstructure Effect of Intermediate Coat Layer on Corrosion Behavior of HVAF-Sprayed Bi-Layer Coatings', J. Therm. Spray Technol., vol. 26, no. 1-2, pp. 243-253, Jan. 2017.

[21] E. Sadeghimeresht, H. Hooshyar, N. Markocsan, S. Joshi, and P. Nylén, 'Oxidation Behavior of HVAF-Sprayed NiCoCrAlY Coating in H2-H2O Environment', Oxid. Met., pp. 1-16, Jul. 2016.

[22] E. Sadeghimeresht, N. Markocsan, and P. Nylén, 'A Comparative Study of Corrosion Resistance for HVAF-Sprayed Fe- and Co-Based Coatings', Coatings, vol. 6, p. 16, Mar. 2016.

[23] E. Sadeghimeresht, N. Markocsan, M. Huhtakangas, and S. Joshi, 'Isothermal oxidation of HVAF-sprayed Ni-based chromia, alumina and mixed-oxide scale forming coatings in ambient air', Surf. Coat. Technol., vol. 316, pp. 10-21, Apr. 2017.

[24] E. Sadeghimeresht, N. Markocsan, and S. Joshi, 'Isothermal oxidation behavior of HVAF-sprayed Ni and NiCr coatings in H2-H2O environment', Surf. Coat. Technol., vol. 317, pp. 17-25, May 2017.

[25] K. A. Habib, M. S. Damra, J. J. Carpio, I. Cervera, and J. J. Saura, 'Performance of NiCrAlY Coatings Deposited by Oxyfuel Thermal Spraying in High Temperature Chlorine Environment', J. Mater. Eng. Perform., vol. 23, no. 10, pp. 3511-3522, Oct. 2014.

[26] M. A. Olivas-Ogaz, J. Eklund, J.-E. Svensson, J. Liske, and T. Jonsson, 'Microstructural Study of the Influence of KCl and $\mathrm{HCl}$ on Preformed Corrosion Product Layers on Stainless Steel', Oxid. Met., vol. 87, no. 5-6, pp. 801-811, Jun. 2017.

[27] C. A. Schneider, W. S. Rasband, and K. W. Eliceiri, 'NIH Image to ImageJ: 25 years of image analysis', Nat. Methods, vol. 9, no. 7, pp. 671-675, Jul. 2012.

[28] J. Lehmusto, D. Lindberg, P. Yrjas, B.-J. Skrifvars, and M. Hupa, 'Thermogravimetric studies of high temperature reactions between potassium salts and chromium', Corros. Sci., vol. 59, pp. 55-62, Jun. 2012.

[29] E. Sadeghimeresht, N. Markocsan, and P. Nylén, 'Microstructural and electrochemical characterization of Ni-based bilayer coatings produced by the HVAF process', Surf. Coat. Technol., vol. 304, pp. 606-619, Oct. 2016.

[30] B. B. He, Two-dimensional X-ray diffraction. John Wiley \& Sons, 2011.

[31] M. H. Enayati, F. Karimzadeh, M. Tavoosi, B. Movahedi, and A. Tahvilian, 'Nanocrystalline NiAl Coating Prepared by HVOF Thermal Spraying', J. Therm. Spray Technol., vol. 20, no. 3, pp. 440-446, Oct. 2010

[32] S. T. Bluni and A. R. Marder, 'Effects of Thermal Spray Coating Composition and Microstructure on Coating Response and Substrate Protection at High Temperatures', Corrosion, vol. 52, no. 3, pp. 213-218, Mar. 1996.

[33] N. Birks, G. H. Meier, and F. S. Pettit, Introduction to the High Temperature Oxidation of Metals. Cambridge University Press, 2006

[34] R. Bender and M. Schütze, 'The role of alloying elements in commercial alloys for corrosion resistance in oxidizingchloridizing atmospheres part I: Literature evaluation and thermodynamic calculations on phase stabilities', Mater. Corros., vol. 54, no. 8, pp. 567-586, 2003. 
[35] N. Israelsson, K. A. Unocic, K. Hellström, T. Jonsson, M. Norell, J.-E. Svensson, L.-G. Johansson, 'A Microstructural and Kinetic Investigation of the $\mathrm{KCl}$-Induced Corrosion of an $\mathrm{FeCrAl}$ Alloy at $600{ }^{\circ} \mathrm{C}$ ', Oxid. Met., vol. 84, no. 1-2, pp. 105-127, Aug. 2015.

[36] S. Kiamehr, K. V. Dahl, M. Montgomery, and M. a. J. Somers, 'KCl-induced high temperature corrosion of selected commercial alloys', Mater. Corros., vol. 66, no. 12, pp. 1414-1429, Dec. 2015.

[37] S. Enestam, D. Bankiewicz, J. Tuiremo, K. Mäkelä, and M. Hupa, 'Are $\mathrm{NaCl}$ and $\mathrm{KCl}$ equally corrosive on superheater materials of steam boilers?', Fuel, vol. 104, pp. 294-306, 2013.

[38] Y. Shu, F. Wang, and W. Wu, 'Corrosion Behavior of Pure Cr with a Solid NaCl Deposit in O2 Plus Water Vapor', Oxid. Met., vol. 54, no. 5-6, pp. 457-471, Dec. 2000.

[39] Y. S. Li and M. Spiegel, 'Internal Oxidation of Fe-Al Alloys in a $\mathrm{KCl}$-Air Atmosphere at $650^{\circ} \mathrm{C}$ ', Oxid. Met., vol. 61, no. 3-4, pp. 303-322, Apr. 2004.

[40] R. A. Antunes and M. C. L. de Oliveira, 'Corrosion in biomass combustion: A materials selection analysis and its interaction with corrosion mechanisms and mitigation strategies’, Corros. Sci., vol. 76, pp. 6-26, Nov. 2013.

[41] N. Israelsson, K. Hellström, J.-E. Svensson, and L.-G. Johansson, 'KCl-Induced Corrosion of the FeCrAl Alloy Kanthal ${ }^{\circledR} \mathrm{AF}$ at $600{ }^{\circ} \mathrm{C}$ and the Effect of H2O', Oxid. Met., vol. 83, no. 1-2, pp. 1-27, Feb. 2015.

[42] R. Bender and M. Schütze, 'The role of alloying elements in commercial alloys for corrosion resistance in oxidizingchloridizing atmospheres. Part II: Experimental investigations', Mater. Corros., vol. 54, no. 9, pp. 652-686, 2003.

[43] A. Roine, 'HSC Chemistry'. Outokumpu Research Oy, Pori, Finland, 2002.

\section{Captions of Table and Figure}

\section{Tables}

Table 1. HVAF process parameters used to spray the $\mathrm{NiCr}$ and $\mathrm{NiAl}$ coatings

\section{Figures}

Fig. 1. Back-scattered SEM micrographs of cross-sections of the as-sprayed coatings, a) NiCr, b) NiAl.

Fig. 2. Surface topography (SEM: SE mode) of the polished coatings, a) NiCr, and b) NiAl.

Fig. 3. XRD patterns of the $\mathrm{NiCr}$ and $\mathrm{NiAl}$ powders and the corresponding polished coatings.

Fig. 4. Weight gain of the exposed $\mathrm{NiCr}$ and $\mathrm{NiAl}$ coatings in $5 \% \mathrm{O}_{2}+500 \mathrm{ppm} \mathrm{HCl}+\mathrm{N}_{2}$ up to $168 \mathrm{~h}$ at $600{ }^{\circ} \mathrm{C}$ with and without $\mathrm{KCl}$ deposit.

Fig. 5. Micrographs of the polished and exposed $\mathrm{NiCr}$ and $\mathrm{NiAl}$ coatings in $5 \% \mathrm{O}_{2}+500 \mathrm{ppm} \mathrm{HCl}+\mathrm{N}_{2}$ for $168 \mathrm{~h}$ at $600{ }^{\circ} \mathrm{C}$ with and without $\mathrm{KCl}$ deposit. The samples were cut for the metallographic preparation.

Fig. 6. XRD patterns of the exposed coatings in $5 \% \mathrm{O}_{2}+500 \mathrm{ppm} \mathrm{HCl}+\mathrm{N}_{2}$ for $168 \mathrm{~h}$ at $600{ }^{\circ} \mathrm{C}$ with and without $\mathrm{KCl}$ deposit, a) $\mathrm{NiCr}$, b) $\mathrm{NiAl}$.

Fig. 7. SEM topographic micrographs (BSE mode) of the $\mathrm{NiCr}$ coatings exposed in $5 \% \mathrm{O}_{2}+500 \mathrm{ppm} \mathrm{HCl}+\mathrm{N}_{2}$ for $168 \mathrm{~h}$ at $600{ }^{\circ} \mathrm{C}$ and corresponding EDS point analysis, a) $\mathrm{NiCr}$ without $\mathrm{KCl}, \mathrm{b}$ ) $\mathrm{NiCr}$ with $\mathrm{KCl}$, c) $\mathrm{NiAl}$ without $\mathrm{KCl}$, and d) $\mathrm{NiAl}$ with $\mathrm{KCl}$.

Fig. 8. Cross-sectional SEM micrograph (BSE) and EDS elemental mapping analysis of the NiCr coating oxidized in $5 \% \mathrm{O}_{2}+500 \mathrm{ppm} \mathrm{HCl}+\mathrm{N}_{2}$ for $168 \mathrm{~h}$ at $600{ }^{\circ} \mathrm{C}$ without $\mathrm{KCl}$ deposit.

Fig. 9. Cross-sectional SEM micrograph (BSE) and EDS point analysis of the $\mathrm{NiCr}$ coating oxidized in $5 \% \mathrm{O}_{2}+$ $500 \mathrm{ppm} \mathrm{HCl}+\mathrm{N}_{2}$ for $168 \mathrm{~h}$ at $600{ }^{\circ} \mathrm{C}$ without $\mathrm{KCl}$ deposit, a) middle of the coating, and b) coating/substrate interface.

Fig. 10. Cross-sectional SEM micrograph (BSE) and EDS elemental mapping analysis of the NiCr coating oxidized in $5 \% \mathrm{O}_{2}+500 \mathrm{ppm} \mathrm{HCl}+\mathrm{N}_{2}$ for $168 \mathrm{~h}$ at $600{ }^{\circ} \mathrm{C}$ with $\mathrm{KCl}$ deposit, a) low magnification, and b) high magnification.

Fig. 11. Cross-sectional SEM micrograph (BSE) and EDS point and elemental mapping analysis of the $\mathrm{NiCr}$ coating oxidized in $5 \% \mathrm{O}_{2}+500 \mathrm{ppm} \mathrm{HCl}+\mathrm{N}_{2}$ for $168 \mathrm{~h}$ at $600{ }^{\circ} \mathrm{C}$ with $\mathrm{KCl}$ deposit, a) middle of the coating, and b) coating/substrate interface. 
Fig. 12. Cross-sectional SEM micrograph (BSE) and EDS elemental mapping analysis of the NiAl coating oxidized in $5 \% \mathrm{O}_{2}+500 \mathrm{ppm} \mathrm{HCl}+\mathrm{N}_{2}$ for $168 \mathrm{~h}$ at $600{ }^{\circ} \mathrm{C}$ without $\mathrm{KCl}$ deposit.

Fig. 13. Cross-sectional SEM micrograph (BSE) and EDS elemental mapping analysis of the NiAl coating oxidized in $5 \% \mathrm{O}_{2}+500 \mathrm{ppm} \mathrm{HCl}+\mathrm{N}_{2}$ for $168 \mathrm{~h}$ at $600{ }^{\circ} \mathrm{C}$ with $\mathrm{KCl}$ deposit.

Fig. 14. Ni-, Al-, Cr-, O-Cl phase stability diagram at $600{ }^{\circ} \mathrm{C}$ calculated with $\mathrm{HSC}$ chemistry 6.0. $p \mathrm{MCl}_{\mathrm{x}} \mathrm{O}_{\mathrm{y}}=10^{-}$ ${ }^{4}$ bar. Equilibrium composition of the test condition is marked with a star. 
Table 1. HVAF process parameters used to spray the $\mathrm{NiCr}$ and $\mathrm{NiAl}$ coatings

\begin{tabular}{cc}
\hline Variables & \\
\hline Nozzle type $^{*}$ & $3 \mathrm{~L} 2 \mathrm{G}$ \\
Air pressure, MPa & 0.8 \\
Fuel 1 pressure-Propane, MPa & 0.7 \\
Fuel 2 pressure-Propane, MPa & 0.7 \\
Carrier gas pressure-N2, MPa & 0.4 \\
Feed rate, g/min & 150 \\
Pass velocity, m/min & 50 \\
Pass spacing, mm/rev. & 5 \\
Spray distance, mm & 300 \\
Number of Passes & 8 \\
\hline
\end{tabular}



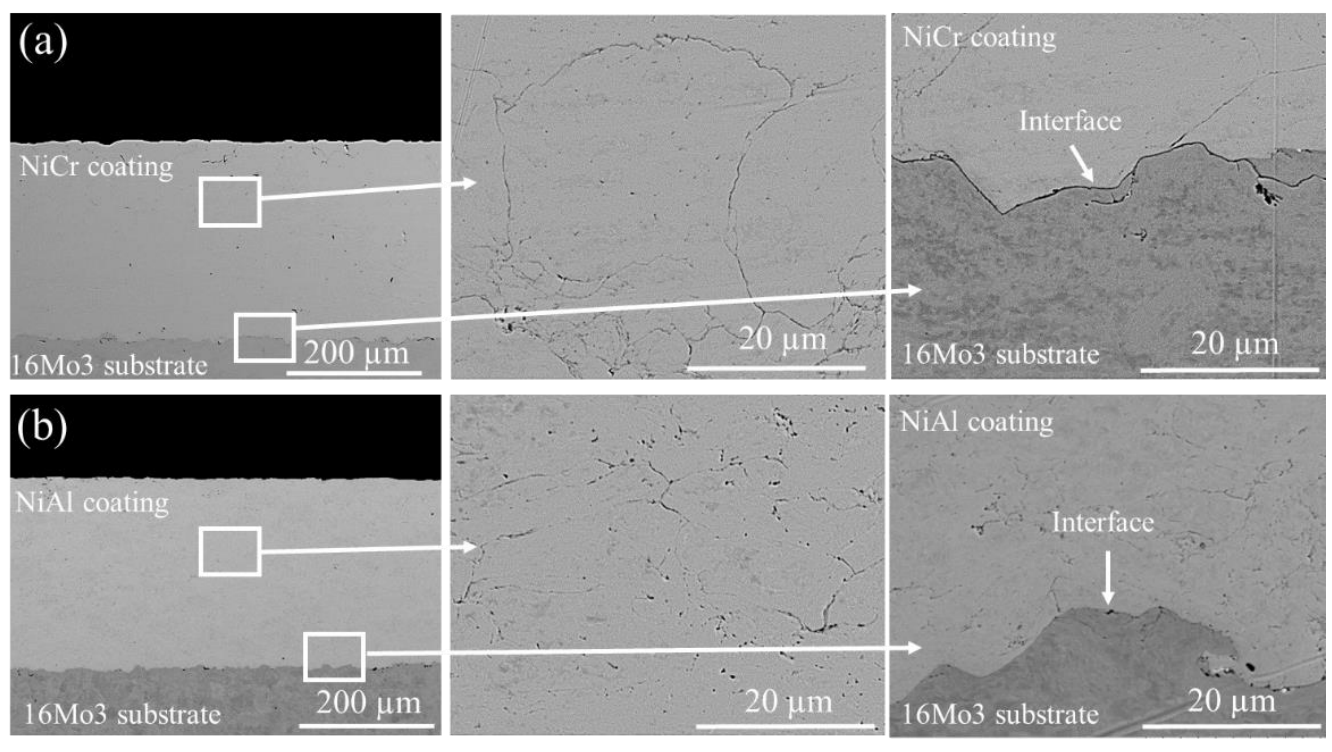

Fig. 1. Back-scattered SEM micrographs of cross-sections of the as-sprayed coatings, a) NiCr, b) NiAl.
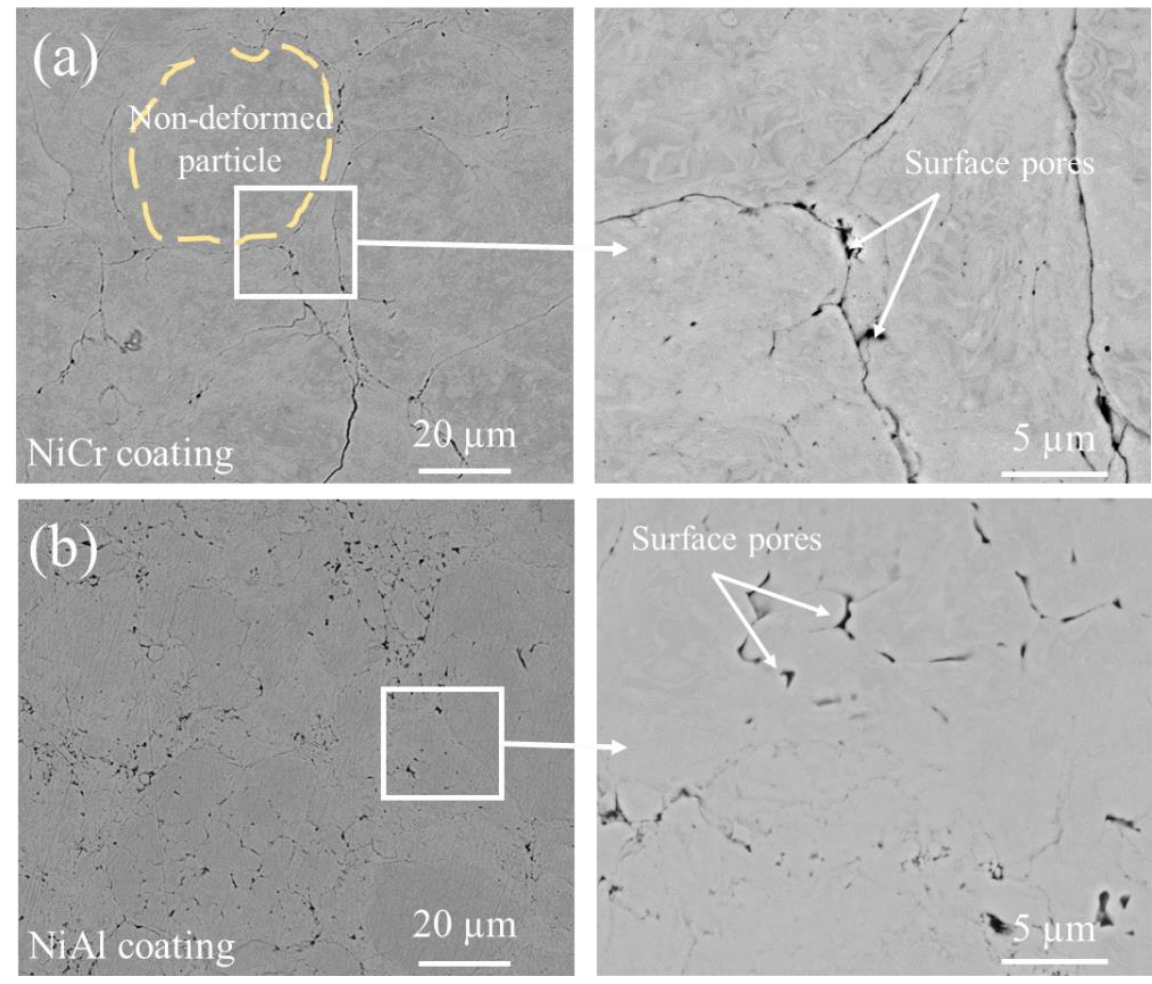

Fig. 2. Surface topography (SEM: SE mode) of the polished coatings, a) NiCr, and b) NiAl. 


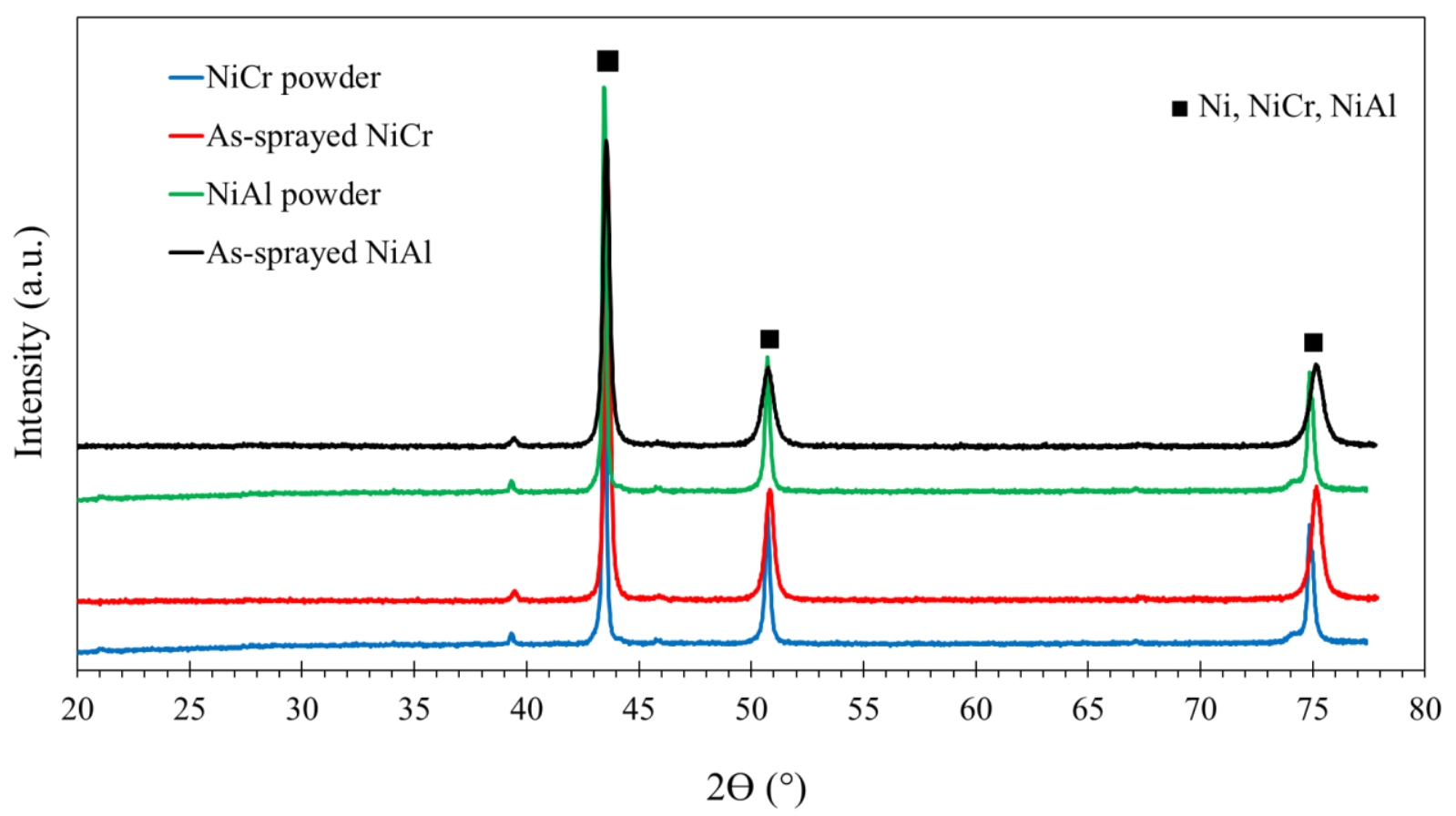

Fig. 3. XRD patterns of the $\mathrm{NiCr}$ and $\mathrm{NiAl}$ powders and the corresponding polished coatings.

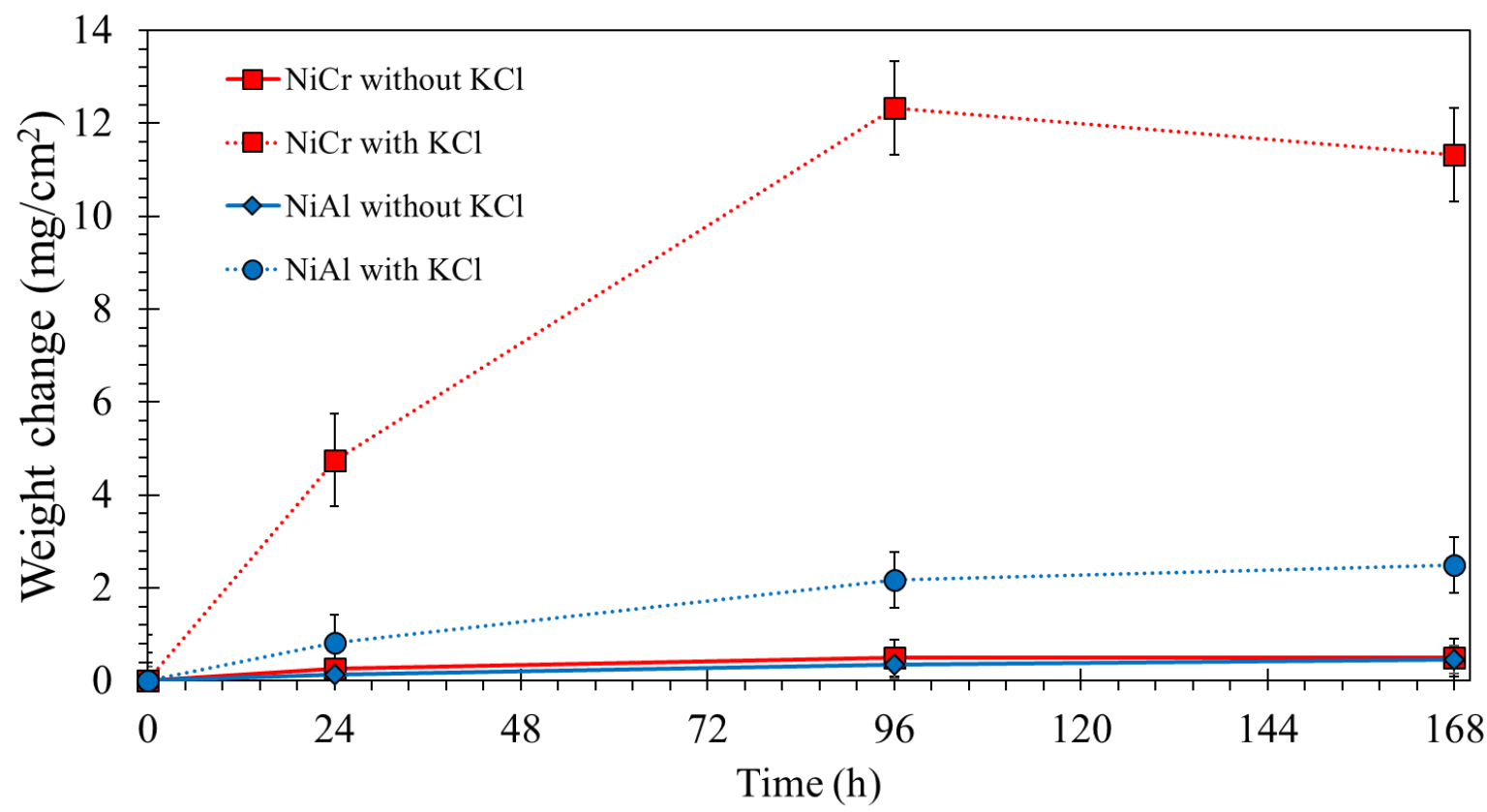

Fig. 4. Weight gain of the exposed $\mathrm{NiCr}$ and $\mathrm{NiAl}$ coatings in $5 \% \mathrm{O}_{2}+500 \mathrm{ppm} \mathrm{HCl}+\mathrm{N}_{2}$ up to $168 \mathrm{~h}$ at $600{ }^{\circ} \mathrm{C}$ with and without $\mathrm{KCl}$ deposit. 


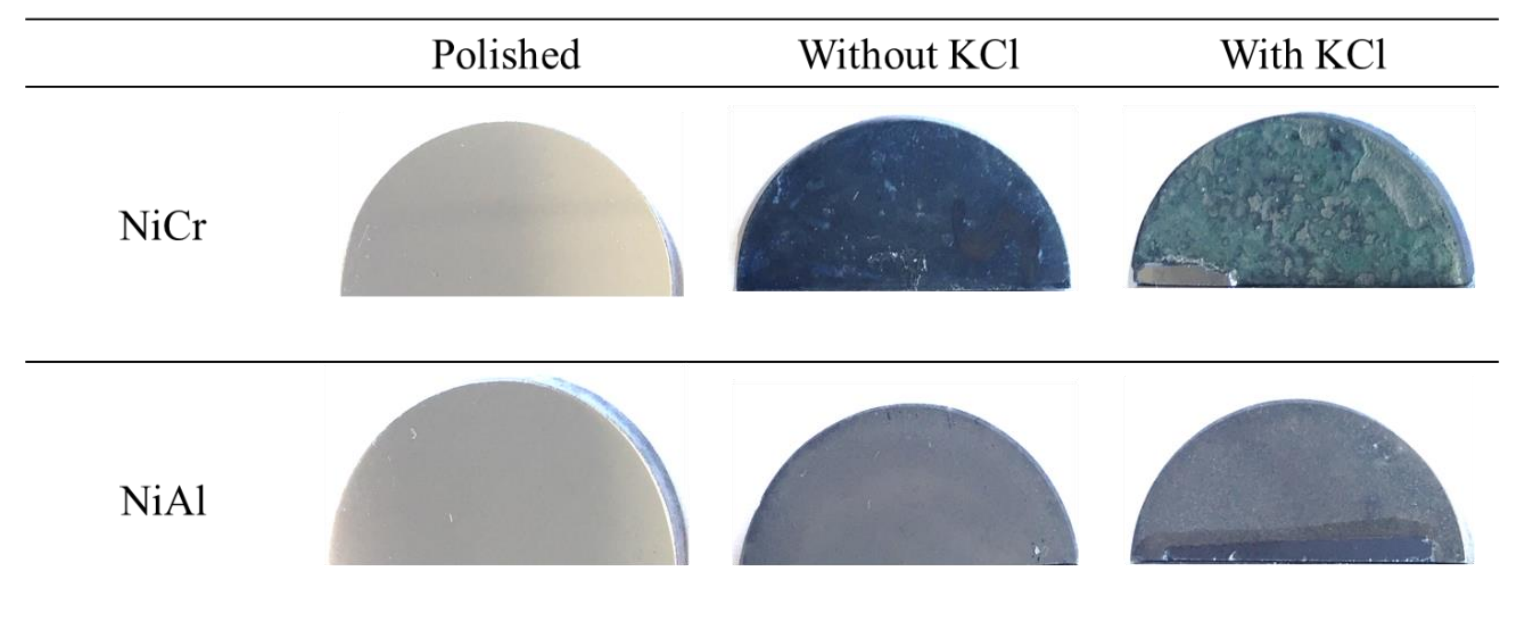

Fig. 5. Micrographs of the polished and exposed $\mathrm{NiCr}$ and $\mathrm{NiAl}$ coatings in $5 \% \mathrm{O}_{2}+500 \mathrm{ppm} \mathrm{HCl}+\mathrm{N}_{2}$ for $168 \mathrm{~h}$ at $600{ }^{\circ} \mathrm{C}$ with and without $\mathrm{KCl}$ deposit. The samples were cut for the metallographic preparation.

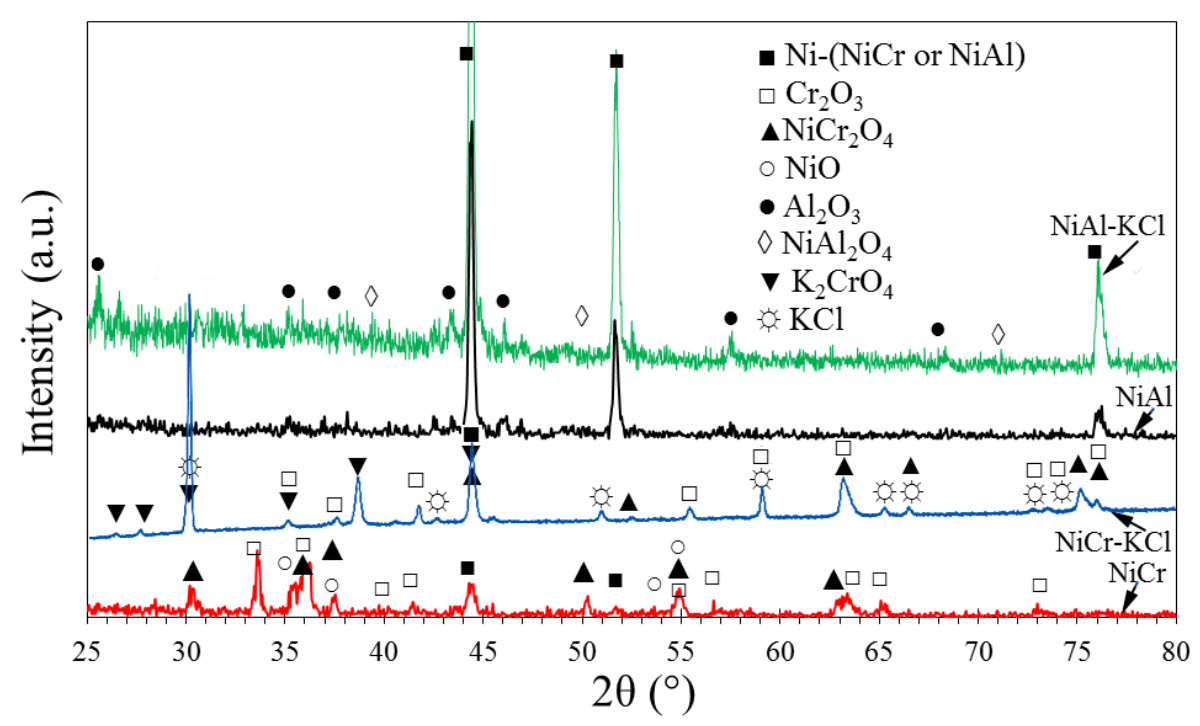

Fig. 6. XRD patterns of the exposed coatings in $5 \% \mathrm{O}_{2}+500 \mathrm{ppm} \mathrm{HCl}+\mathrm{N}_{2}$ for $168 \mathrm{~h}$ at $600{ }^{\circ} \mathrm{C}$ with and without $\mathrm{KCl}$ deposit, a) NiCr, b) NiAl. 

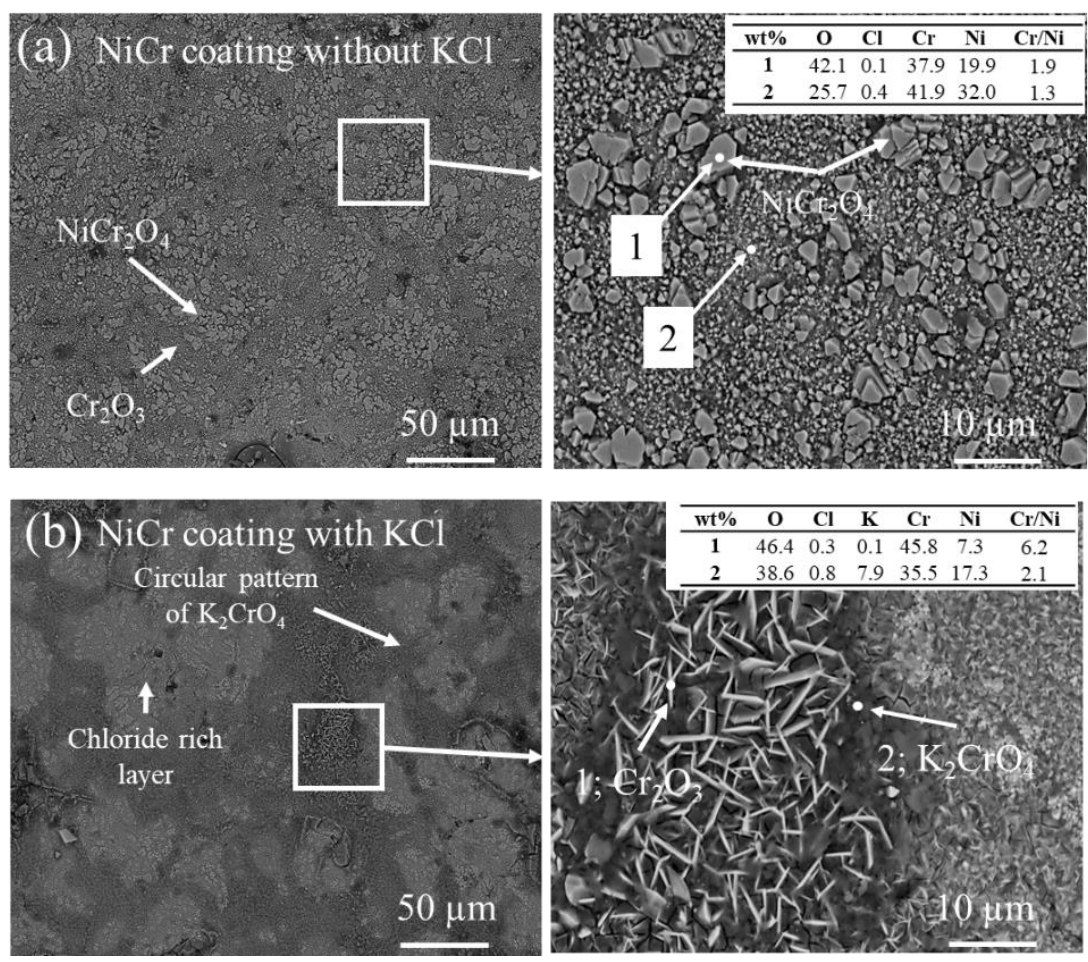

Fig. 7. SEM topographic micrographs (BSE mode) of the $\mathrm{NiCr}$ coatings exposed in $5 \% \mathrm{O}_{2}+500 \mathrm{ppm} \mathrm{HCl}+\mathrm{N}_{2}$ for $168 \mathrm{~h}$ at $600{ }^{\circ} \mathrm{C}$ and corresponding EDS point analysis, a) $\mathrm{NiCr}$ without $\mathrm{KCl}$, b) $\mathrm{NiCr}$ with $\mathrm{KCl}$, c) $\mathrm{NiAl}$ without $\mathrm{KCl}$, and d) $\mathrm{NiAl}$ with $\mathrm{KCl}$.
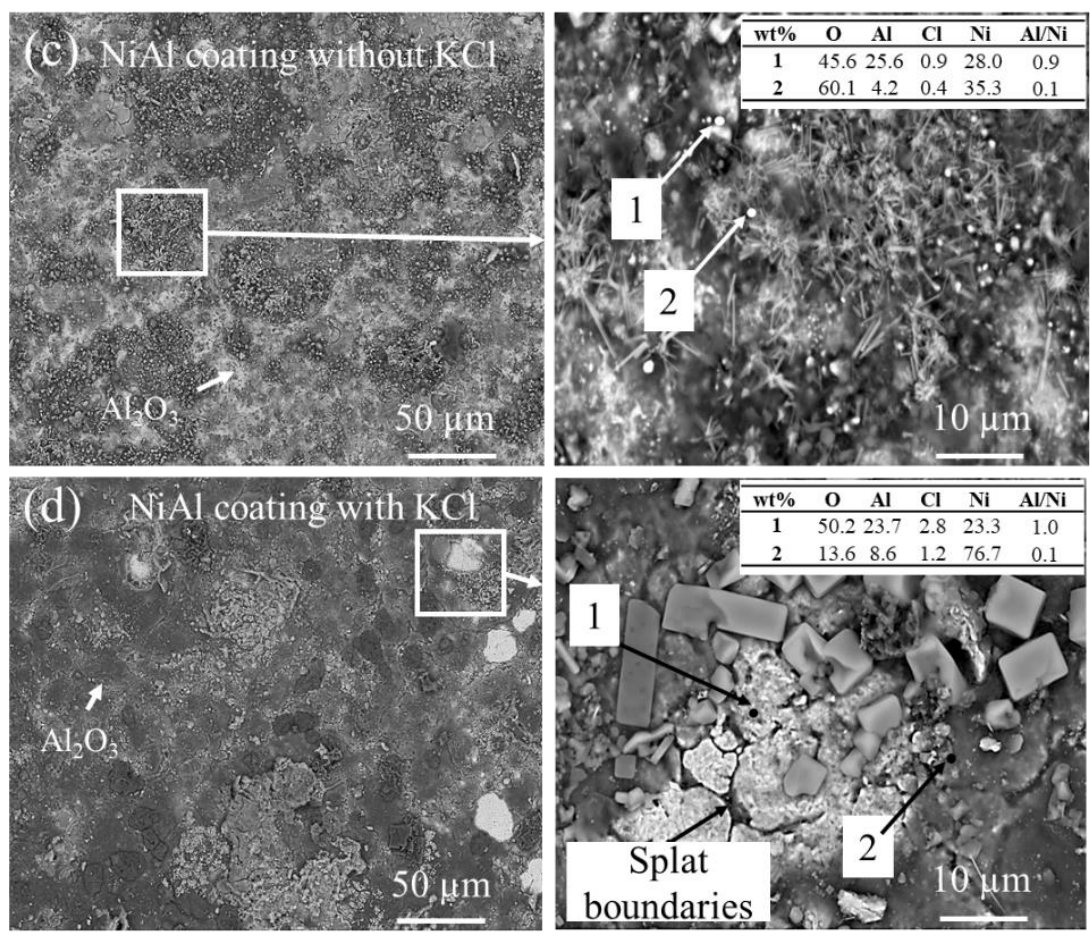

Fig. 8. Cross-sectional SEM micrograph (BSE) and EDS elemental mapping analysis of the $\mathrm{NiCr}$ coating oxidized in $5 \% \mathrm{O}_{2}$ $+500 \mathrm{ppm} \mathrm{HCl}+\mathrm{N}_{2}$ for $168 \mathrm{~h}$ at $600{ }^{\circ} \mathrm{C}$ without $\mathrm{KCl}$ deposit. 

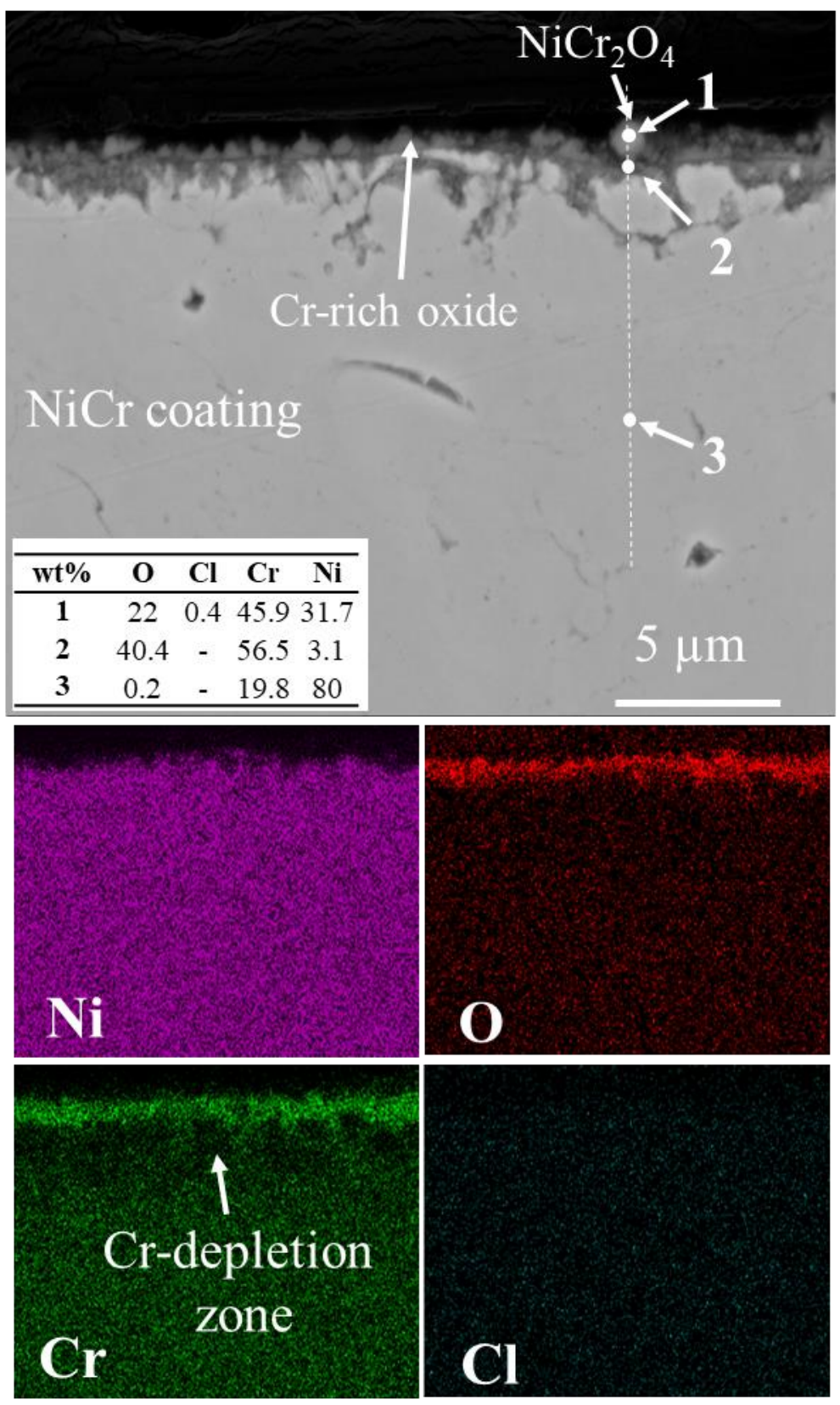

Fig. 9. Cross-sectional SEM micrograph (BSE) and EDS point analysis of the $\mathrm{NiCr}$ coating oxidized in $5 \% \mathrm{O}_{2}+500 \mathrm{ppm}$ $\mathrm{HCl}+\mathrm{N}_{2}$ for $168 \mathrm{~h}$ at $600{ }^{\circ} \mathrm{C}$ without $\mathrm{KCl}$ deposit, a) middle of the coating, and b) coating/substrate interface. 


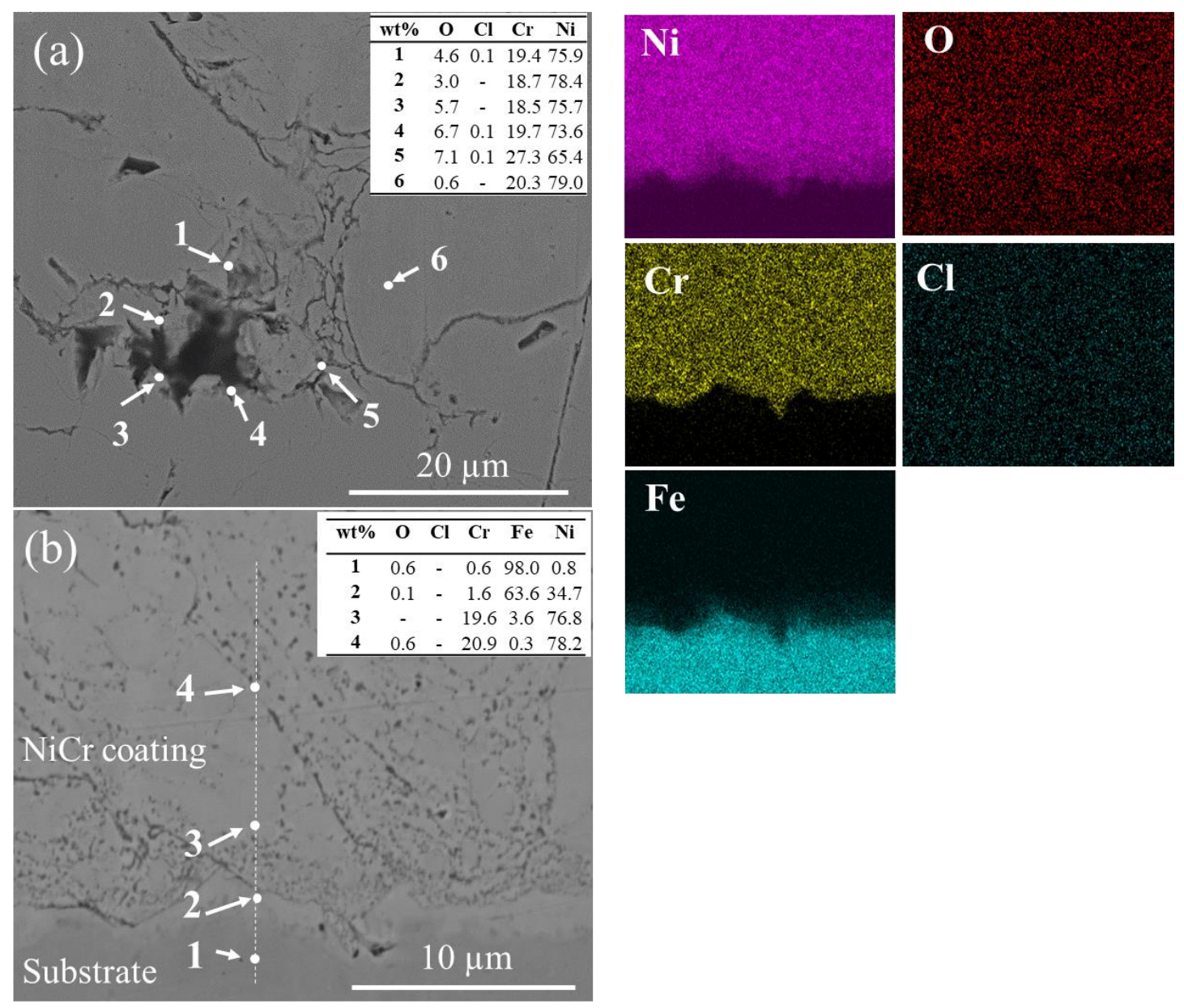

Fig. 10. Cross-sectional SEM micrograph (BSE) and EDS elemental mapping analysis of the $\mathrm{NiCr}$ coating oxidized in $5 \% \mathrm{O}_{2}$ $+500 \mathrm{ppm} \mathrm{HCl}+\mathrm{N}_{2}$ for $168 \mathrm{~h}$ at $600{ }^{\circ} \mathrm{C}$ with $\mathrm{KCl}$ deposit, a) low magnification, and b) high magnification. 

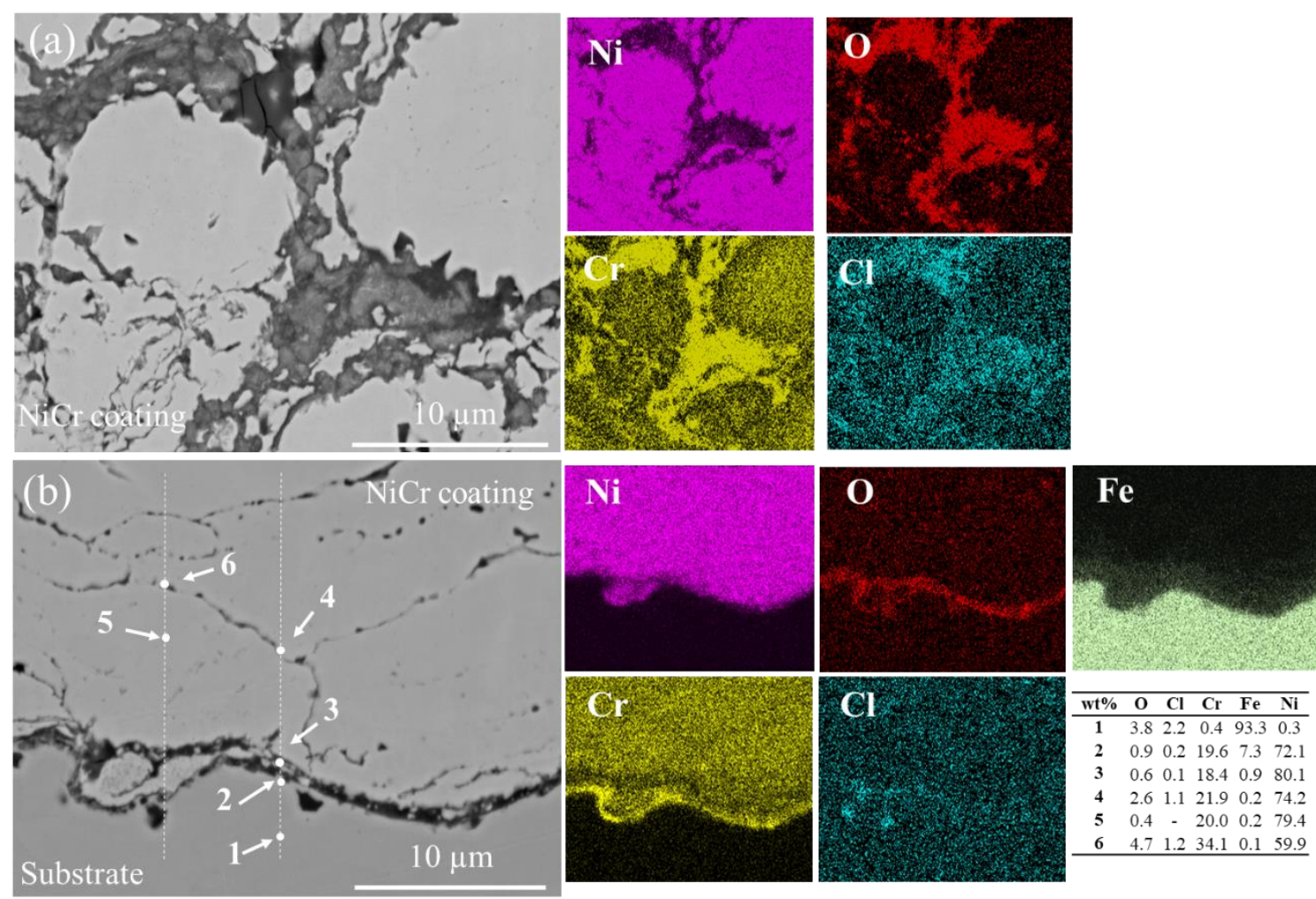

Fig. 11. Cross-sectional SEM micrograph (BSE) and EDS point and elemental mapping analysis of the NiCr coating oxidized in $5 \% \mathrm{O}_{2}+500 \mathrm{ppm} \mathrm{HCl}+\mathrm{N}_{2}$ for $168 \mathrm{~h}$ at $600{ }^{\circ} \mathrm{C}$ with $\mathrm{KCl}$ deposit, a) middle of the coating, and b) coating/substrate interface. 


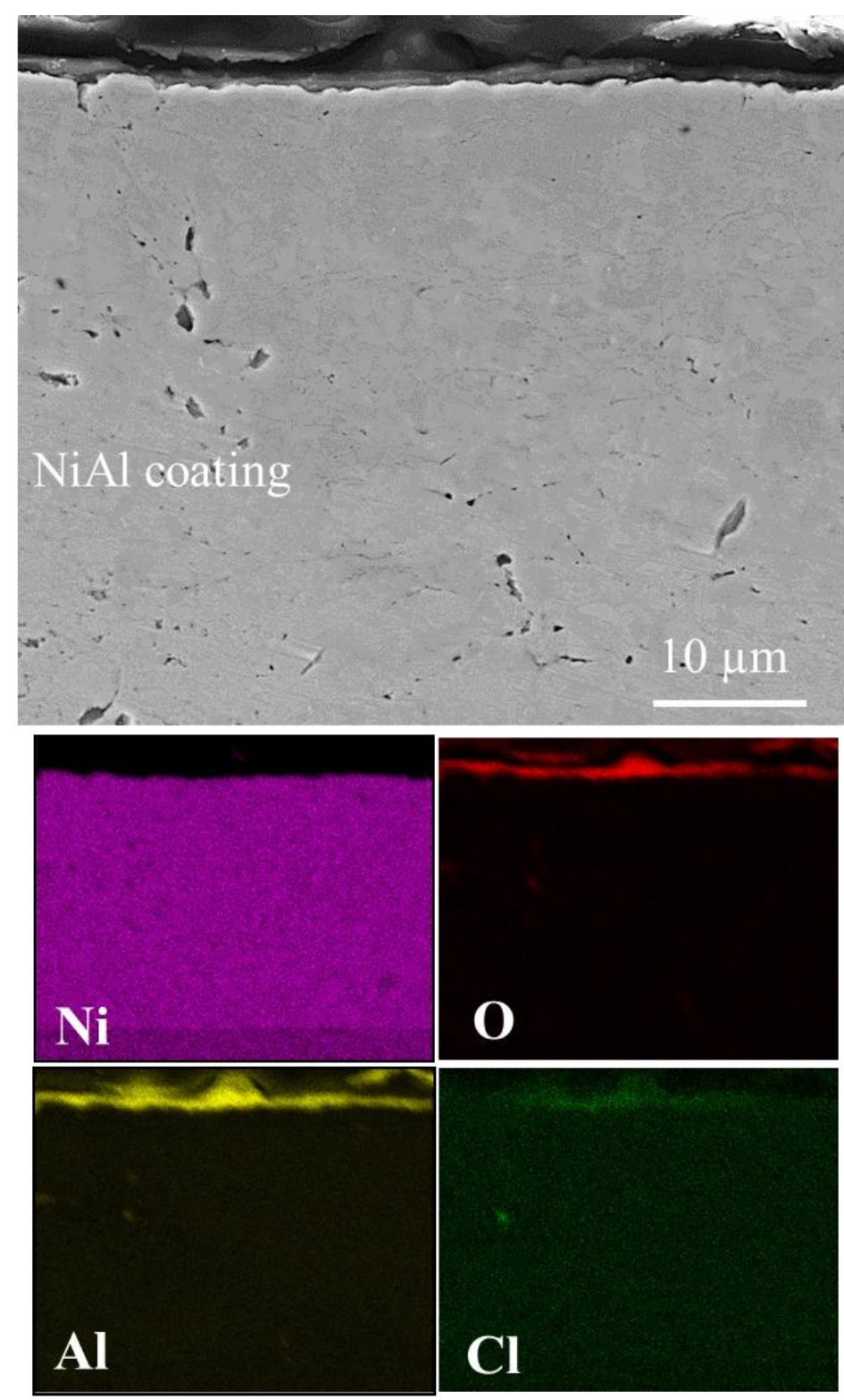

Fig. 12. Cross-sectional SEM micrograph (BSE) and EDS elemental mapping analysis of the $\mathrm{NiAl}$ coating oxidized in $5 \% \mathrm{O}_{2}$ $+500 \mathrm{ppm} \mathrm{HCl}+\mathrm{N}_{2}$ for $168 \mathrm{~h}$ at $600{ }^{\circ} \mathrm{C}$ without $\mathrm{KCl}$ deposit. 

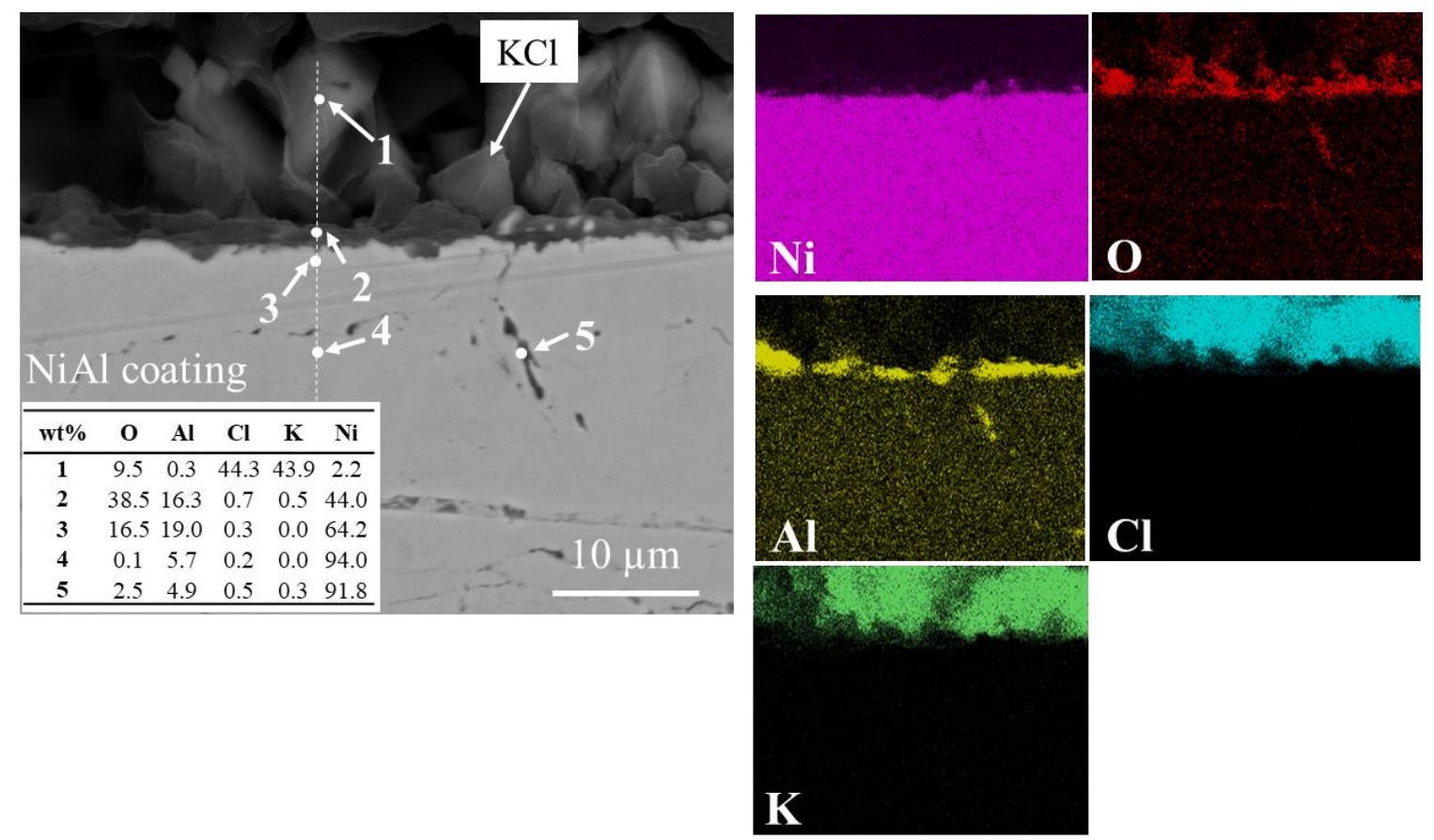

Fig. 13. Cross-sectional SEM micrograph (BSE) and EDS elemental mapping analysis of the NiAl coating oxidized in $5 \% \mathrm{O}_{2}$ $+500 \mathrm{ppm} \mathrm{HCl}+\mathrm{N}_{2}$ for $168 \mathrm{~h}$ at $600{ }^{\circ} \mathrm{C}$ with $\mathrm{KCl}$ deposit.

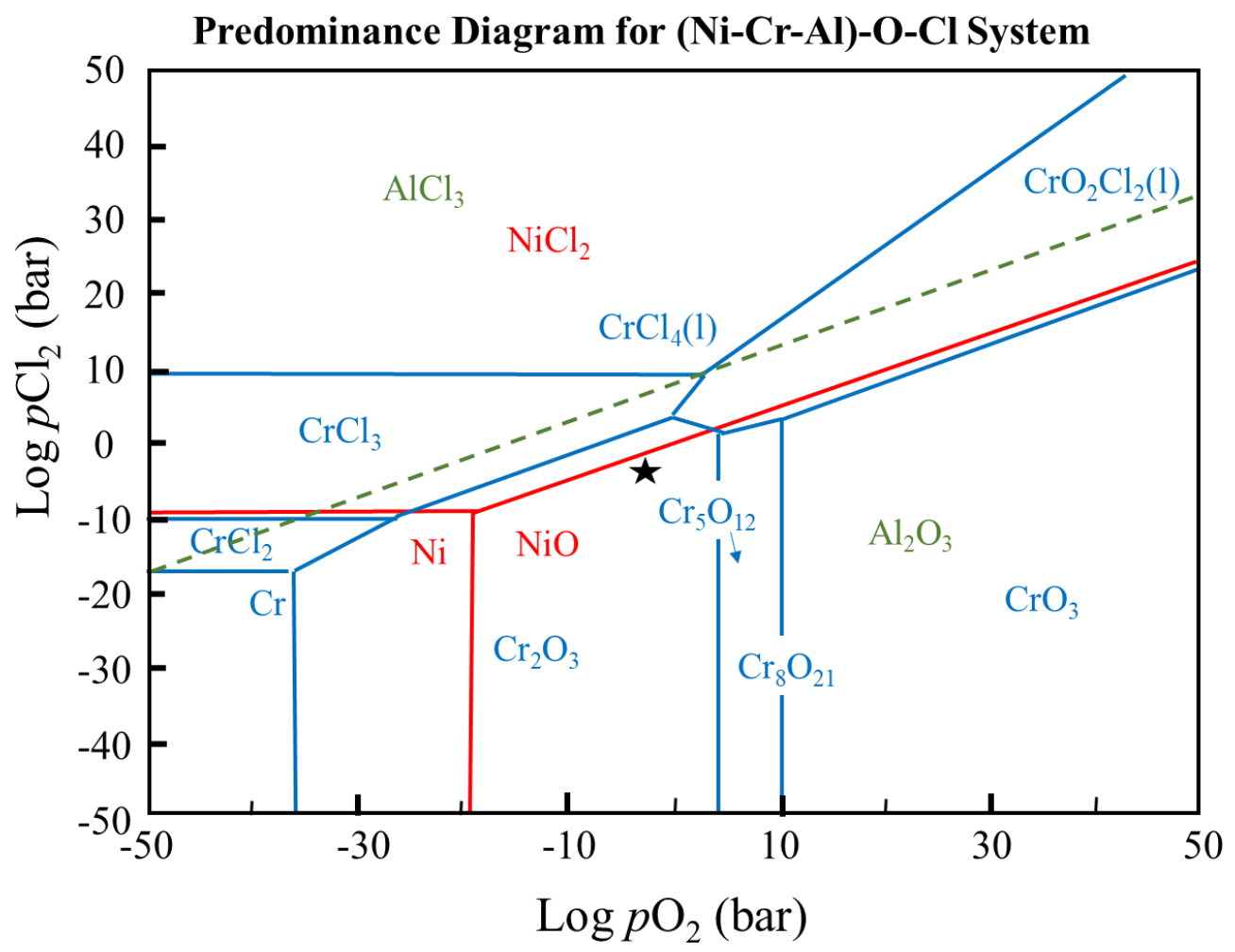

Fig. 14. Ni-, Al-, Cr-, O-Cl phase stability diagram at $600{ }^{\circ} \mathrm{C}$ calculated with $\mathrm{HSC}$ chemistry 6.0. $p \mathrm{MCl}_{\mathrm{x}} \mathrm{O}_{\mathrm{y}}=10^{-4}$ bar. Equilibrium composition of the test condition is marked with a star. 
